\title{
MODERN APPROACHES TO CENTRAL BANKING
}

Stanley Fischer

Working Paper No. 5064

\author{
NATIONAL BUREAU OF ECONOMIC RESEARCH \\ 1050 Massachusetts Avenue \\ Cambridge, MA 02138 \\ March 1995
}

This is an edited version of a paper presented at the Bank of England's Tercentenary Celebration, London, June 9, 1994. I am grateful to my discussants at the conference, Don Brash, Miguel Mancera, and Josef Tosovsky for useful comments, to Guy Debelle for research assistance, and to Michael Bruno, John Crow, Charles Freedman and Mervyn King for discussions and the provision of literature. This paper is part of NBER's research program in Monetary Economics. Any opinions expressed are those of the author and not those of the National Bureau of Economic Research.

(ㄷ) 1995 by Stanley Fischer. All rights reserved. Short sections of text, not to exceed two paragraphs, may be quoted without explicit permission provided that full credit, including $(\odot$ notice, is given to the source. 


\title{
MODERN APPROACHES TO \\ CENTRAL BANKING
}

\begin{abstract}
Modern theory has delivered both the conservative central banker and the principal-agent approaches as rationales for the independence of the central bank. The principal-agent approach directs attention to the importance of both clearly defining the goals of the central bank and its command in order to meet the targets assigned to it. The empirical evidence shows not only that greater independence is associated with lower inflation, but also that the central bank's rights not to finance the government and to set interest rates independently increase its effectiveness. The role of inflation targeting and the distinction between price level and inflation targeting are also analyzed.
\end{abstract}

\section{Stanley Fischer}

International Monetary Fund

Room 12-300F

700 19th Street, NW

Washington, DC 20431

and NBER 


\section{MODERN CENTRAL BANKING}

stanley Fischer ${ }^{1}$

The practice and theory of modern central banking revolve around the inflationary tendencies inherent in the conflict between the short- and long-run effects of monetary expansion, and in the temptations of monetary financing of government spending. They should also revolve around the conflict between the benefits of shielding the central bank from political pressures and the principle of accountability to the public of those who make critically important policy decisions.

The earliest central banks were set up to provide financing for governments, and to help develop the financial system, often by bringing order to the note issue. ${ }^{2}$ As the practice of central banking developed during the nineteenth century, the central bank took on the primary responsibility for protecting the stability of the financial system and the external value of the currency. The mandate given to the central bank in legislation passed during the 1930 s and 1940 s--in the Great Depression and the heyday of the Keynesian revolution--typically included both monetary stability and the promotion of full employment and maximum levels of production. Then, as the inflationary forces that destroyed the Bretton woods system gathered strength in the 1960 s

International Monetary Fund (on leave from MIT), and Research Associate, NBER. This is an edited version of a paper presented at the Bank of England's Tercentenary Celebration, London, June 9, 1994. I am grateful to my discussants at the conference, Don Brash, Miguel Mancera, and Josef Tosovsky for useful comments, to GuY Debelle for research assistance, and to Michael Bruno, John Crow, Charles Freedman and Mervyn King for discussions and the provision of literature.

'See de Kock (1974) for the historical development of central banking, as well as the interesting companion paper for this conference by Capie, Goodhart and schnadt (1994). 
and 1970s, the focus of monetary policy shifted to the maintenance of the domestic value of the currency.

The trend is summarized by the contrast between the absence of a specific mandate for the Bank of England in the Bank Act of $1946^{3}$ and the very specific goals set out for the Reserve Bank of New Zealand in the Act of 1989, "The primary function of the Bank is to formulate and implement monetary policy directed to the economic objective of achieving and maintaining stability in the general level of prices."

I shall start this lecture by briefly reviewing the functions and goals of central banks--the mandates set out for them in legislation, and in some cases the mandates they have chosen in interpreting conflicting legislative goals. In recent years, central banks have increasingly come to emphasize the fight against inflation and to deemphasize the possibility that monetary policy can affect the level of output; I therefore turn next to the changing views of the Phillips curve tradeoff, and economic analysis of the costs of inflation.

The rational expectations revolution in macroeconomics and the growing sophistication of game-theoretic models have radically changed the academic analysis of policy-making. For the first time, economists can talk analytically about such key issues as credibility, rules versus discretion, and central bank independence. I will briefly describe some of the relevant analysis of credibility and of rules versus discretion, and draw practical lessons for policy.

\footnotetext{
${ }^{3}$ The Bank of England's 1694 Charter starts "Now know ye, That we being desirous to promote the publick Good and Benefit of our People"; this section was embodied in the 1946 Bank of England Act.
} 
In the remainder of the lecture I concentrate on the key issue of central bank independence, its analytics, and the empirical evidence. I conclude by describing the charter of a modern central bank.

\section{Central Bank Functions and Mandates}

Central banks around the world perform a variety of functions. Through their control over the monetary base--their role as "bank of issue" in an earlier terminology--all have the responsibility for managing the supply of credit and money and correspondingly determining market interest rates. Sometimes, as in Britain, the Treasury or the finance ministry makes the decisions on interest rates, and leaves only their implementation to the central bank. The central bank may be fully or jointly responsible for determining the exchange rate and managing the foreign exchange reserves. Central banks hold the reserves of the commercial banks and play a role in managing the payments system. Most are given responsibility for promoting the stability of the financial system, by supervising the banks and other financial institutions, by serving as lender of last resort, and in some countries by administering deposit insurance. The central bank is usually the government's banker; central banks often administer foreign exchange controls; in some countries they manage all or part of the national debt; the research department of the central bank may often be the best and sometimes the only policy research group in the country; the central bank may have a development banking function.

A country, particularly a developing country, derives many benefits from having a highly professional, highly respected central bank. The capacity and the reputations of, for examples, the central banks of Israel, 
Italy, and Mexico have all played a key role in helping bring about stabilization and stability in their countries. But I will take a narrow perspective on central banking in this lecture, by concentrating on the essential central bank function, monetary policy--management of the supply of credit and money, and thus of money market interest rates. The lender of last resort function typically accompanies this responsibility. Exchange rate and foreign reserve management can hardly be divorced from interest rate determination, though the treasury frequently shares or is responsible for these tasks. 4 Comnercial bank supervision is generally the responsibility of the central bank, but in some countries is carried out in a separate agency. 5 Management of the national debt by the treasury or another agency avoids conflict between the government's desire to keep debt service low and the goals of monetary policy. Whether or not the central bank is the government's banker, coordination between the fiscal authority's management of government cash flow, and the central bank is important.

Control over the supply of money and credit gives the central bank potentially enormous power. In countries where the central bank has sufficient independence to determine interest rates, the goals towards which that power should be deployed are often specified in legislation. The Bundesbank is directed to conduct monetary policy "with the aim of 4 The choice of the exchange rate system, as opposed to the management of the chosen system, is normally a central government rather than a central bank decision.

The question of whether the central bank or another agency should supervise the commercial banks has been extensively discussed (see for example paragraphs 83-103 of volume I of the Treasury and Civil service Committee report The Role of the Bank of England, London: EMso, 1993; this report is referred to henceforth as The Role of the Bank of England). The weight of the evidence supports the view that the supervisory function should remain with the central bank, but the issue is not crucial. 
safeguarding the currency"; it is also required to support the general economic policy of the Federal Government, but only to the extent that this is consistent with its primary goal of safeguarding the currency. ${ }^{6}$ The Act of August 4 1993, amended December 31 1993, gives the Banque de France the aim of ensuring price stability, within the framework of the Government's overall economic policy. This is similar to the Bundesbank mandate, but without the provision that the price stability mandate overrides the obligation to support government economic policy. Like the Bundesbank, the Reserve Bank of New Zealand is charged with producing price stability. The Federal Reserve is given a more general charge, 7 to "maintain long-run growth of the monetary and credit aggregates commensurate with the economy's long run potential to increase production, so as to promote effectively the goals of maximum employment, stable prices, and moderate long-term interest rates." There are no clearly set out goals for the Bank of England; indeed there is a logical difficulty in specifying independent policy goals for a non-independent agency .

Where goals are either unclear or multiple, central banks may succeed in setting their own priorities. For instance the Swiss National Bank is required "to regulate the country's money circulation, to facilitate payment transactions, and to pursue a credit and monetary policy serving the interests of the country as a wholen. As the SNB explained to the House of Commons Treasury and Civil Service Committee last year "The SNB understands

${ }^{1}$ shall focus most directly on four central banks: the Bundesbank, the Reserve Bank of New Zealand, the Federal Reserve System, and the Bank of England.

7 This the goal of monetary policy set out in the Humphrey-Hawkins Act of 1978 . ${ }^{8}$ The Role of the Bank of England, Volume II, p175. 
this ... primarily as a mandate for ensuring price stability with the instruments at its disposal." Similarly, the Bank of Japan, whose 1942 legislation requires it to enhance the nation's general economic activities, states that "its objectives are commonly described as 'to maintain price stability' and 'to foster the soundness and stability of the financial system'" .9

Table 1 presents a tabulation of the legally-specified objectives of 72 central banks, whose charters have been studied by Cukierman, Webb and Neyapti (1992). The objectives are scaled by the degree to which they emphasize price stability relative to other goals. These are the goals that existed in legislation as of the 1980s. 10 Two-thirds of the countries in both the overall sample and the industrialized country group include price stability among the goals of the central bank; it is also true that two-thirds of the central banks are either not given an explicit price stability mandate or are given one that is mentioned together with a conflicting goal, for example the maintenance of full employment.

In the period since the data were tabulated, several central banks have moved up in the table, among them the central banks of France and others that plan to join the European System of Central Banks, New Zealand, and Mexico. And, as we have seen, several of the central banks which do not have explicit or sole price stability targets, interpret their mandates as emphasizing price stability. Increasingly, the debate over the role and mandate of central banks focuses on the question of whether the central bank

9 The Role of the Bank of England, Volume II, p165.

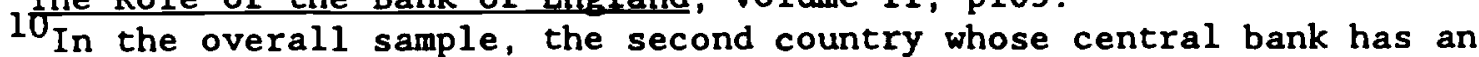
overriding price stability goal is that of the Philippines. 
should be given the sole or primary task of assuring price stability or low inflation.

Why should this be, when monetary policy affects both output and prices in the short run? The answer starts from the well-known history of the Phillips curve.

\section{The Phillips Curve}

The original 1958 Phillips curve showed a century-long relationship between wage inflation and unemployment in the United Kingdom. A century surely qualifies as a long run, and so it should not be surprising that some economists of the time concluded that the curve represented a trade-off menu of choices facing the government, in which the benefits of lower inflation have to be balanced against their costs in terms of higher unemployment. The Phillips curve was brought to the United States by Paul Samuelson and Robert Solow (1960), who after presenting the menu view of the curve, warned that their discussion dealt only with the short run, and that it would be wrong to think that the same tradeoff would be maintained in the longer run. 11 Nonetheless, United States experience through the 1960's presented the appearance of a simple Phillips curve tradeoff, as unemployment steadily declined and inflation gradually increased (Figure 1). But that of course was only the beginning of the story. As the textbooks tell us ${ }^{12}$, even before the

\footnotetext{
il Samuelson and Solow gave two examples of how the curve would shift: first, that low inflation might shift the curve down because of its impact on expectations; second, that structural unemployment might rise as a result of higher unemployment, so that the curve would shift up. Both these possibilities have been central to subsequent discussions, the first as the expectations-augmented Phillips curve, the second as the phenomenon of hysteresis (Blanchard and Summers, 1986).

${ }^{12}$ See for example, Dornbusch and Fischer (1994), Chapter 16.
} 
end of the 1960s Edmund Phelps (1967) and Milton Friedman (1968) predicted that the PhIllips curve would shift as expectations of inflation adjusted to actual inflationary experience. Unemployment could not be kept permanently below its natural rate, and attempts to do so would lead only to accelerating inflation. The experience of the next two decades, shown in Figure 2, certainly supported their prediction that the curve would shift.

The Phillips curve had been presented as an empirical phenomenon, and rationalized as an example of the law of supply and demand which asserts that excess demand causes the price of a good to rise. Friedman and Phelps pointed out that wage negotiators bargain about the real wage, and that nominal wage increases would therefore be adjusted to reflect expectations of inflation. This destroyed the theoretical basis for assuming a long-run tradeoff between inflation and unemployment; the facts seen in Figure 2 destroyed the empirical basis for assuming that there is any simple form of long-run tradeoff. We shall return to the question of the long-run tradeoff below.

In the Friedman-Phelps Phillips curve, it is only errors in expectations that permit unemployment to differ from the natural rate. Friedman and Phelps assumed that expectations were formed adaptively, ${ }^{13}$ so that the monetary authority could for a time keep unemployment low by accelerating the inflation rate. As inflation accelerated, workers--forming their expectations with a lag--would continually underpredict inflation, the real wage would remain below its equilibrium level, and employment would exceed its equilibrium level. With the addition of the assumption of rational 13 That is, expectations of inflation are assumed to adjust on the basis of the gap between actual and expected inflation. 
expectations, Lucas (1973) destroyed even the short-run Phillips curve tradeoff. In his model, no predictable monetary policy has any effects on output, because the private sector takes the monetary policy into account, adjusts its expectations accordingly, and there is no possibility of a systematic gap between expected and actual inflation.

The Lucas no short-run tradeoff view would, if correct, imply that systematic monetary policy can only affect the inflation rate, and should therefore be deployed to that end. But while the view that there is no longrun tradeoff between inflation and unemployment is widely accepted, the no short-run tradeoff view is not. The most obvious reason not to accept the no short-run tradeoff proposition is that central banks have demonstrated repeatedly that they can create recessions by tightening monetary policy. It does not take sophisticated econometric analysis to recognize that the Fed produced a recession in 1981-82 as it successfully reduced inflation. Romer and Romer (1989) have more systematically shown that Fed policy decisions to tighten monetary policy have been followed by recessions. A second reason not to accept the no short-run tradeoff view is the econometric evidence that predictable monetary policy affects output and not only prices. 14

The question remains of why there is a short-run Phillips curve tradeoff. The short-run tradeoff in the Lucas (1973) model is the result of confusion by buyers and sellers about the meaning of changes in nominal prices; in that model, even unpredictable monetary policy would have no real effect of any kind if there were perfect information about the current money stock or aggregate price level. A more plausible explanation is that monetary 
policy gets its short-run leverage from the existence of sticky wages and prices, resulting for instance from long-term and perhaps overlapping wage contracts. 15 The stickiness may result more fundamentally from costs of changing individual prices ${ }^{16}$ or renegotiating wages.

The terms of the short-run tradeoff between output and inflation may depend on the average rate of inflation. Because prices in a high inflation economy have to be changed frequently, any excess monetary expansion is likely to be taken into account in a price change within a short time. In a low inflation economy, by contrast, prices need not be changed very often, and so prices are likely to respond less rapidly to a monetary expansion. This would mean that the short-run Phillips curve is flatter in a low inflation economy than in a high inflation economy. 17

The existence of a short-run tradeoff between output and inflation is central to the day-to-day decisions confronting monetary policy-makers. There is no escaping the fact that it is almost always possible to increase output by accelerating money growth, 18 or to cause a recession by tightening credit sufficiently. Even if there is no long-run tradeoff between inflation and real output, there is a short-run tradeoff.

${ }^{15}$ See for instance, Fischer (1977); Blanchard (1986) shows how even quite short-term overlapping contracts may generate lengthy adjustment processes to nominal shocks.

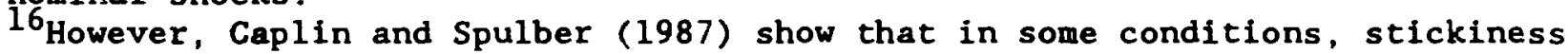
of prices at the level of the individual firm does not translate into stickiness at the aggregate level; Caplin and Leahy (1991) examine conditions in which the Caplin-Spulber neutrality result does not hold.

17 This theory is developed by Ball, Mankiw and Romer (1988), who present supporting evidence. The short-run Phillips curve derived by Lucas (1973) is flatter the lower the variance of the aggregate inflation rate; and since the level of the inflation rate and its variance are in practice positively correlated, the Lucas model can also be seen as predicting that the short-run Phillips curve is flatter at lower inflation rates.

${ }^{18}$ The qualifier takes care of the possibility that extra monetary expansions have no effect in extreme hyperinflations. 
The social benefits of one part of that tradeoff, the increase in output and decline in unemployment brought about by expansionary policy, appear to be obvious. 19 We need to consider the other part of the tradeoff, the social costs of higher inflation, in more detail.

\section{The Costs of Inflation}

Reporting to the House of Commons in 1810, the Select Committee on the High Price of Gold Bullion dealt summarily with the costs of inflation (in this case high prices): 20

Your committee conceive that it would be superfluous to point out, in detail, the disadvantages which mist result to the country from any such general excess of currency as lowers its value.

Almost two centuries later, it is still often said we lack an account of the costs of inflation that matches the intensity with which inflation is denounced by policymakers and disliked by. the general public. It is more accurate to say that while there are convincing accounts of the many costs of inflation, especially in a society that has not adapted to its existence, the costs have been difficult to quantify. ${ }^{21}$

Table 2 presents a reasonably complete listing of the costs of inflation, which depend on the institutional structure of the economy and on

19 However the issue is not as analytically straightforward as it seems. If the economy is at an undistorted equilibrium, with the marginal value of leisure equal to the real wage, an expansion in output brought about by fooling workers as in the Friedman-Lucas model, does not increase their welfare. In the presence of distortions that make the natural rate of unemployment exceed the socially optimal level, or at a monopolistic competition equilibrium, an increase in output beyond the equilibrium level will be socially beneficial. 20 Pp cclviil-cclvix, reprinted by Arno Press, New York, 1978.

21 Keynes (1924) provides one of the earliest analyses. I draw here on Fischer and Modigliani (1978), and Fischer (1981). See also Driffill et al (1990). 
the extent to which the inflation has been anticipated. Rather than work through the table in detail, I will summarize the major categories of costs, and then go on to discuss recent work relating the growth of output and productivity to inflation.

The most analyzed cost of inflation is the money triangle or shoeleather costs, 22 the social cost of economizing on the use of non-interest bearing money. The area of the triangle depends on the magnitude of the relevant money stock and on the elasticity of money demand with respect to the nominal interest rate. For simplicity, we take currency to be the relevant concept of money. The average ratio of currency to GNP in the G-7 in 1992 was 5.2 percent. The average inflation rate (CPI) for these seven countries for the period 1989-92 was 4.5 percent. ${ }^{23}$ Assuming an interest elasticity of 0.25 , and that the nominal interest rate is 2 percent when the inflation rate is zero, a reduction in the inflation rate to zero would increase the stock of currency to 7 percent of GNP. The welfare gained as a result of that decline in inflation would amount only to 0.03 percent of GDP.

of course, these small welfare costs apply only at low inflation rates. 24 When inflation reaches the triple digit range, the social costs of attempting to economize on currency become high. Financial departments of firms expand at the expense of production, consumers spend time and resources

22 The classic reference is Bailey (1956).

23 These are unweighted averages, based on data in the International Financial statistics. The relevant base for the inflation tax includes non-interest bearing bank reserves, but since interest is paid on some bank reserves in the G-7, for instance in Italy, I work with the currency stock. The average ratio of high-powered money to GNP in the G-7 in 1992 was 7.8 percent, and the social costs would rise proportionately if this were the relevant money stock. ${ }^{24}$ Lucas (1994) shows that the welfare loss depends significantly on the functional form of the demand for money. 
delaying payments, and this social cost of inflation rises--approximately with the square of the inflation rate.

The money triangle calculation implicitly assumes the existence of non-distorting taxes to compensate for revenues lost by reducing inflation. If lump-sum taxes are available, then Friedman (1969) showed that the optimal inflation rate is not zero but rather that inflation rate which satiates the economy with real balances by driving the nominal interest rate to zero. Absent lump-sum taxes, the inflation tax may form part of an optimal tax package, so that the optimal inflation rate could be positive. However, the fiscal approach to inflation provides no clear theoretical presumption as to whether the optimal inflation tax is positive. 25

There are two other potential effects of even a fully anticipated inflation. First, savers may substitute capital for real balances in their portfolio as inflation increases. ${ }^{26}$ This would offset the steady state costs of the inflation. The portfolio substitution effect is bound to be small at low inflation rates, because the money displacement effect is itself small. In addition, inflation would generate menu costs--the costs of more frequent changes of prices. Menu costs have not been measured, but it is hard to believe they would amount to much in a low inflation economy.

The familiar conclusion so far is that the costs of any fully anticipated inflation rate below say 5 percent, in an economy whose

25 Phelps (1973) initiated the optimal tax analysis of inflation. For more recent general equilibrium analyses, see Cooley and Hansen (1991), and Chari et al (1991). The optimal inflation tax is zero in the latter model. Faig (1988) also establishes conditions under which it is optimal not to tax money holdings.

${ }^{26}$ Theory makes no unambiguous predictions in this case either: in infinite horizon maximizing models, such as that of Sidrauski (1967), inflation would not affect the steady state capital stock; in an overlapping generations model, or a model with a cash-in-advance constraint, it can. 
institutions have adapted to inflation, must be moderate indeed. If inflation has significant costs, they must arise from the non-adaptation of institutions to inflation, and because inflation is often not anticipated.

The most important source of institutional non-neutrality to inflation is the tax system; within the tax system it is the taxation of capital that is most distorted by inflation. The deductibility of nominal interest and the taxation of nominal capital gains are the two main distortions. Assuming that the effective tax rate on saving rises with inflation, and making a host of subsidiary assumptions, it is possible to calculate the costs of lower rates of capital accumulation implied by higher inflation. 27 In addition, rising rates of taxation associated with inflation cause misallocations of capital among sectors, and affect corporate financing decisions. In the presence of bracket creep, rising inflation would also affect labor supply.

Taken together, such inflation-caused distortions could easily have a social cost amounting to $2-3$ percent of GNP at an inflation rate of 10 percent. 28 However, there is a very real question of whether these costs should be attributed to inflation, for most of them could be removed by indexing the tax system. Income tax brackets have been Indexed in the United States but indexation of capital taxation is generally more cumbersome and rare.

The assumption of a constant value of money is also built into private sector institutions, including the typical level-payment nominal

27 Fischer (1981) contains one such calculation, in which an increase in the inflation rate from zero to 10 percent has a social cost of 0.7 percent of GNP as a result of its impact on saving.

${ }^{28}$ See Fischer (1981). 
mortgage in the United States, and accounting practices. There has been an increasing recognition of inflation in both areas in the last two decades, with a corresponding reduction in the costs of inflation. It has also become more common to recognize the effects of inflation-caused increases in interest rates on government fiscal data, with the notion of the operational deficit gaining increasing usage in moderate-to-high inflation countries. 29

Unanticipated inflations are associated with redistributions of income and wealth, the latter of which may be massive. Keynes (1924) argued that entrepreneurs gain from inflation, and it is often believed that labor loses. However, the direction of any redistribution of income must depend on the source of the inflationary shock and, at least in the moderate inflations in the United States, the estimated redistributions are small.

Inflation-induced wealth redistributions are larger, both between the private and public sectors, and within the private sector between debtors and creditors. Taking the Maastricht norm, at a debt to GDP ratio of 60 percent an increase in the price level by one percent reduces the value of government debt by 0.6 percent of GDP. Unanticipated changes in the price level thus have potentially large impacts on private sector wealth. However because a reduction in the value of government debt reduces future taxes, these redistributions should be viewed as intergenerational within the private

29 The operational or inflation-adjusted deficit deducts the decline in the real value of government debt caused by inflation from the nominal deficit. In analyzing inflation stabilizations, there is also a case for calculating a "zero-inflation deficit", an estimate of what the deficit would be if inflation were reduced to zero. This would differ from the operational deficit because inflation affects other components of the budget, for example through the Tanzi effect, and because the real interest rate might change if inflation were stabilized. The zero-inflation deficit is an indicator of the extra fiscal effort that would be needed for a stabilization program to succeed. 
sector rather than between public and private sectors, with unanticipated inflation reducing the wealth of the old and increasing that of the young. This is certainly one source of the political unpopularity of inflation. Within the private sector, unanticipated inflation benefits the debtors. Corporations appear to gain at the expense of their lenders, though equities do not generally benefit from inflation--so that unanticipated inflation benefits neither bondholders nor equityholders. Mortgage borrowers gain at the expense of depositors and other lenders.

The wealth redistributions associated with even moderate rates of unanticipated inflation are likely to be economically and politically significant. That is all the more so when unanticipated changes in the price level are large, as they have been in the aftermaths of wars. It is however difficult to estimate the social costs of such redistributions, for one group gains what another loses.

A considerable body of evidence establishes that the variability of relative prices rises with the inflation rate, for both anticipated and unanticipated inflation. In both cases, it is likely that the increased variability of relative prices distorts the allocation of resources. ${ }^{30}$ These inflation-related distortions must be part of the explanation for the negative association between growth and inflation to be documented below.

Finally, high inflation is also more uncertain inflation. 31 There are several possible reasons for this relationship: inflation is often associated with real shocks; the higher the inflation rate, the more likely it

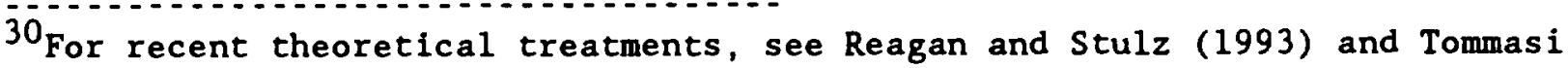
(1994).

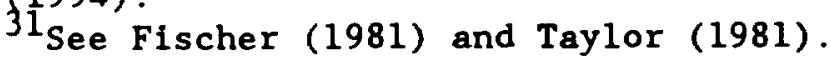


is that the government will want to reduce the inflation rate at some point; higher inflation is a signal of a government that is losing control over the economy. Whatever the cause, the higher uncertainty is costly, potentially reducing investment ${ }^{32}$, and also reducing the welfare of savers forced to contend with it. The welfare costs for savers of greater uncertainty are related to the potential benefits of the introduction of indexed bonds. Sample calculations in Fischer (1981) suggest that an increase in the uncertainty of inflation typically associated with a rise in inflation within the range of recent United States experience would create no more than a modest social cost.

This long list establishes the many ramifications of inflation, anticipated and unanticipated, in a modern economy even at moderate rates of inflation. Adding together those elements in the list that can be quantified would provide an estimate of the costs of a 10 percent inflation at 2-5 percent of GNP. That is a sizable social cost, albeit one that could be significantly reduced by indexation.

But it remains true that such an enumeration does not capture the very strong feelings about inflation that are evident even in the less inflation-averse industrialized economies. Some of the popular attitude must derive from the belief that inflation unfairly takes away the fruits of inflation-caused nominal income increases that people incorrectly attribute to their own merit and hard work. ${ }^{33}$ Another factor must be the disorientation of

32 Huizinga (1991) presents a model in which uncertainty reduces investment as entrepreneurs wait for its resolution before committing themselves. It should be noted though that the general equilibrium effects of greater uncertainty on investment may differ from the partial equilibrium effects, since asset prices and interest rates can adjust in general equilibrium.

${ }^{33}$ Fischer and Huizinga (1982) examine public opinion polls on attitudes to inflation, but are unable to substantiate this inflation illusion hypothesis. 
having to deal with price increases in the face of the surprisingly deeply inbuilt belief that money values are stable, a form of money illusion. ${ }^{34} \mathrm{~A}$ further cause of the popular view must be the fear that the disorders of hyperinflation lie just over the horizon of any inflation, a fear that is more vivid in countries that have suffered hyperinflations.

Most important, the experience of inflation is rarely that of a simple steady rate of growth of prices at sustained full employment. Rather, inflation is usually associated with other problems, supply shocks or a lack of fiscal control. Yet another cause of the popular attitude must be the generally negative association between output growth and inflation. Indexation.

Many of the costs of inflation would be reduced by the introduction of indexation. This applies to the tax system, to inflation-caused wealth redistributions on debt, and to the losses to savers from the greater uncertainty associated with higher inflation. Here lies the essential case for government introduction of indexed bonds, to reduce the uncertainties confronting those saving for retirement. 35 Indexation of wages would reduce the redistribution of income associated with demand-caused inflation in the presence of long-term labor contracts, and would also make the Phillips curve steeper.

Many governments, and particularly central bankers, have long opposed indexation, on the grounds that its introduction would be a confession

${ }^{34}$ Such money illusion appears to remain in economies that experience single digit inflation, but does not survive in prolonged moderate (15-30 percent) inflations, where a foreign currency is often used as a unit of account and store of value.

35 For discussion of the welfare economics of the introduction of indexed bonds, see Fischer (1983). 
of failure in the battle against inflation, and would weaken the will to continue the fight. 36 In the words of Arthur Burns (1978, p148):

This [indexation] is a counsel of despair. ... I doubt if there is any practical way of redesigning economic contracts to deal with this problem satisfactorily. In any event, if a nation with our traditions attempted to make it easy to live with inflation, rather than resist its corrosive influence, we would slowly but steadily lose the sense of discipline needed to pursue governmental policies with an eye to the permanent welfare of our people.

Game theoretic models provide some support for this view (Fischer and Summers, 1989). In models in which monetary policy has an inflationary bias because of dynamic inconsistency, ${ }^{37}$ any change that reduces the social costs of inflation increases the equilibrium inflation rate, and tends to worsen social welfare, ${ }^{38}$ essentially for the reasons given by the Radcliffe Committee and by Arthur Burns. However, it is necessary to distinguish different types of indexation. Indexing that increases the costs of unanticipated inflation to the government tends to reduce the inflation rate. Thus indexation of taxes and of bonds that reduces the government's gains from unanticipated inflation would not necessarily cause higher inflation: the net effect depends on the relative extents to which such indexation reduces the social costs of inflation compared with the extent to which it reduces the government's gains from unanticipated inflation. Central bankers have not all opposed bond indexation; ${ }^{39}$ nor has the introduction of index bonds in Britain had any obviously adverse effects on the government's will to fight inflation.

\footnotetext{
${ }^{36}$ Report of the Committee on the Working of the Monetary System (the Radcliffe Committee), 1959, para 573.

37 The concept of dynamic inconsistency is discussed in more detail below.

${ }^{38}$ This result holds for the usual quadratic loss function, but may be reversed for other loss functions.

${ }^{39}$ In his February 221994 Humphrey-Hawkins testimony, Fed Chairman Greenspan indicated support for the introduction of index bonds, mainly on informational grounds.
} 
The extent of indexation in an economy is a measure of how much inflation that economy has experienced. It would thus be difficult to establish empirically whether indexation generally weakens the will to fight inflation. However, it is certainly clear from the cases of Israel and Brazil in the early 1980s that the view that the country had learned to live with inflation was instrumental in both the increases in inflation in each and the deterioration of their economic situations.

Widespread indexation that reduces the social costs of inflation for society is likely to increase inflation and quite possibly make the society worse off. Indexation that reduces the government's incentives to inflate by reducing its gains from inflation can make society better off. Inflation. Growth, and Productivity.

At least since the time of David Hume ([1752] 1955), it has been argued that a little inflation is good for growth:

The good policy of the magistrate consists only in keeping it [the money stock], if possible, still increasing; because by that means he keeps alive a spirit of industry in the nation, and increases the stock of labor in which consists all real power and riches.

Early models of money and growth likewise suggested that an increase in inflation would temporarily increase growth, and increase the steady state capital stock as investors substitute capital for real balances in their portfolio. More recent models allow for a negative association between inflation and growth, for example because inflation is associated with greater price variability and greater uncertainty, thereby reducing both the effectiveness of the price mechanism, and investment.

The context here is not the short-run Phillips curve tradeoff, but rather the longer-term relationship between inflation and growth. The 
evidence points strongly to a predominantly negative longer-term relationship between growth and inflation. 40 Cross-country regressions reported in Fischer (1993) show a consistently negative association between inflation and growth. Based on a panel regression for 80 countries over the period 1961-1988, it is estimated that an increase in the inflation rate by 10 percentage points (e.g. from 5 to 15 percent per annum) is associated with a decline in output growth of 0.4 percent per annum. Estimation of a spline regression shows that these inflation effects are non-linear, the marginal effect on growth associated with an increase in inflation declining as inflation rises. The spline regression shows a larger though barely statistically significant effect of higher inflation on growth for inflation in the range of 0.15 percent per annum: in this range, a 10 percentage point increase in the inflation rate is associated with a reduction in the growth rate of output by 1.25 percent per annum.

Decomposing growth into its components due to capital accumulation, productivity growth, and an increase in the growth rate of the labor force, the negative association between inflation and growth can be traced to strong negative relationships between inflation and capital accumulation, and inflation and productivity growth, respectively. A 10 percentage point increase in the inflation rate is associated with a decline in productivity growth of 0.18 percent per annum.

These negative associations do not of course establish that increases in inflation cause lower growth. If higher inflation is caused by

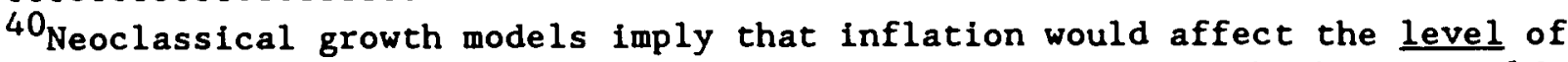
output, but not the steady state growth rate. The new growth theory could generate a growth rate effect of inflation. 
adverse supply shocks, then the negative correlation between inflation and growth merely reflects the common impact of supply shocks. Fischer (1993) attempts to deal with this possibility by breaking the period into two at 1973, the date after which supply shocks became prominent. It turns out that the negative association between growth and inflation exists for both subperiods. While this result is suggestive, it does not entirely dispose of the causation issue; indeed, given that policymakers do not create inflation out of a clear blue sky, it is almost certain that countries with high inflation rates are countries that are already in trouble for fiscal or other reasons, and thus that it will be either impossible or extremely difficult to deal definitively with the issue of causation.

The association between growth and inflation has also been examined for Individual countries. In the Canadian case, Jarrett and Selody (1982) found that a one percentage point reduction in inflation was associated with a 0.3 percent increase in the growth rate. The effect is too large to be causal: if it were, a decline in the irflation rate from 5 percent to zero would increase the growth rate by 1.5 percent, surely a tradeoff anyone would be happy to make.

Rudebusch and Wilcox (1994) examine the closely related issue of the relationship between the rate of productivity growth and inflation. Using United States data, they find that an increase in inflation of 1 percent is associated with a 0.35 percent decline in productivity growth, an even bigger coefficient than in the Canadian case. Figure 3 shows United States data. The estimated coefficient for Canada and the U.K. is almost the same as that for the United States; it is significantly smaller and sometimes insignificant for other members of the G-7. 
Rudebusch and Wilcox attempt to pin down whether the relationship is causal. One possibility is that the relationship reflects cyclical timing patterns: productivity growth is low'near the peak of the cycle, when inflation is high, and high during the early part of the recovery, when inflation is typically still low. Figure 3 certainly suggests a strong cyclical element in the relationship. Making an adjustment for the cycle reduces the regression coefficient. Attempting to deal with the simultaneity issue econometrically, by the use of instrumental variables, Rudebusch and Wilcox find that the coefficient on inflation typically becomes insignificant. While these two approaches suggest the relationship is not causal, Granger causality tests point in the opposite direction, implying that inflation Granger-causes productivity growth rather than vice versa.

In summary, while there is a strong and suggestive negative relation between longer-term growth and inflation, and productivity growth and inflation, the statistical evidence has not yet established that the relationship is causal. One reason to suspect that the relationship is not causal is that the coefficient on inflation in the productivity growth equation is too large. Another is that the relationship does not appear particularly robust. 41

However weak the evidence, one strong conclusion can be drawn: inflation is not good for longer-term growth.

$41_{\text {It }}$ is also puzzling that the coefficient is large and significant only for the English-speaking countries among the G-7. 
IV. The Optimal Inflation Rate: Zero Inflation versus Price Level Stability.

The fiscal view of inflation presents one approach to determining the optimal rate of inflation. However, it is hard to believe that seigniorage can be a significant determinant of the optimal inflation rate in an industrialized economy with a sophisticated tax system. Rather the optimal inflation rate should be determined on the basis of all the costs of inflation, and of any benefits it might have.

The many costs of inflation are manifest. If there is no long-run tradeoff between inflation and unemployment, or inflation and growth, at any positive inflation rate, and absent a fiscal motive for inflation, it is hard to see any benefits. 42 This would suggest a target inflation rate of zero.

Reinforcing this view is the argument that zero is the only credible target, that once the monetary authority agrees to allow some inflation, it cannot plausibly commit to fighting higher inflation. Phelps (1972, p.xvi) characterizes this view ${ }^{43}$ as

Compare 'Price Stability, Right or Wrong', which has a nice ring to it, with 'If I have but one job to give to my economy, let me give it for 5.5 percent inflation, as against higher numbers', which is absurd.

Let me for the moment accept that the target inflation rate should be zero. The important distinction then has to be drawn between a zero inflation target and the target of price level stability. 44 with a target inflation rate of zero, the central bank aims to achieve zero inflation each

42 I do not want to rule out the possibility that the revenue motive may justify positive inflation in countries that have difficulty raising revenues in other ways.

${ }^{43}$ Despite the persuasiveness of the quote. Phelps does not share the view.

${ }^{44}$ This issue has been discussed intensively in the Bank of Canada, which will produce a conference volume on the topic shortly. 
period, that is, to keep the price level at its current level. A central bank committed to price level stability would aim to undo the consequences of past failures to achieve the target price level. With a zero inflation target each period, there is considerable uncertainty about price levels in the distant future. With a price level stability target, there should be much less uncertainty about price levels in the distant future.

Figure 4, one realization of a stochastic simulation, illustrates the difference. ${ }^{45}$ Each period the monetary authority achieves its target price level for that period, up to a random error. With a zero inflation target, the price level is a random walk. This means that the variance of future price levels increases linearly with their distance from the current period. with a price level target, the monetary authority is assumed each period to aim to close half the gap between the current price level and the target price level. This ensures that the actual price level stays close to the target level, and that uncertainty about future price levels is small.

The chief benefit of a price level target is that it keeps uncertainty about price levels in the distant future much smaller than it would be with a zero inflation target. The chief disadvantage is that the monetary authority with a price level target is attempting to deflate the economy half the time: the short-run target inflation rate will be negative half the time. For reasons to be discussed shortly, there are good reasons not to target negative inflation. Price level targeting

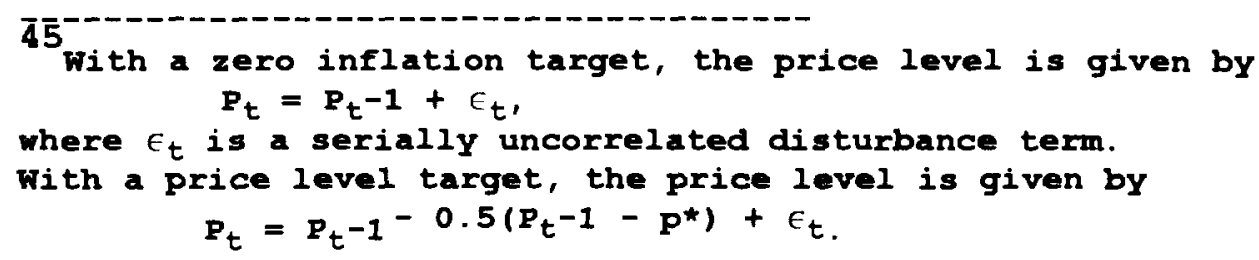


would add unnecessary short-term fluctuations to the economy. It is also true, as can be seen in Figure 5, that there is more variability and uncertainty about short-term inflation rates with a price level target than with a target inflation rate.

It is sometimes said that price level stability is desirable because it would once again make long-term nominal contracting more attractive. Reference is made in this context to 99 -year nominal leases, or the 100 year railroad bonds issued during the nineteenth century, a period in which a substantial measure of price level stability was achieved: in Britain, the same level of prices prevailed in 1914 as in 1881 as in 1844 ; setting that level at 100, prices ranged only between 70 and 130 in the period 1826 to 1914. 46 It is difficult to see much benefit from 99 -year nominal leases or to make the case that 100 year bonds are an economically significant improvement over 50 year bonds, or 30 year bonds. And besides, some 100 year bonds have recently been sold in the United States.

Price level predictability is desirable for those saving for retirement. But it is far easier to provide for a stable real income stream in retirement by issuing index bonds than by trying to maintain a constant value of money.

Uncertainty about future price levels is unlikely to be much greater if the monetary authority targets a small positive inflation rate rather than a zero inflation rate. Thus there is no significant benefit from the viewpoint of the predictability of future price levels between choosing a zero inflation target and a 2-3 percent inflation target.

${ }^{46}$ Data are from Keynes (1924). 
So far I have accepted the zero inflation target. There are however three complications associated with aiming for zero inflation. First, it may sometimes be useful for the real interest rate to be negative. The real interest rate on bills cannot be negative if the inflation rate is zero and the nominal yield on currency, which sets a lower bound to the bill rate, is also zero. 47 The real rate has been negative during recessions, and there is no good reason to deprive monetary policy of the possibility of having an ex ante negative real yield at times. Second, any downward price inflexibility would increase the output costs of negative inflation rates, which would be more frequent with a zero inflation goal. 48 Third, our measures of inflation are biased upwards. Estimates of the bias in the United states are as high as $1.5-2$ percent per annum. 49 It is very hard to see why the central bank should struggle to

$\overline{4} \overline{7}$

This argument is due to summers (1991). There may be a small convenience yield that would allow slightly negative nominal interest rates on large denomination bills; it is also well known that nominal rates were negative at some points during the great depression, but that was a result of special tax features of bills. 48 49 This argument implies money illusion.

49 The three sources of bias are the failure to correct systematically for quality change (estimated to yield a bias of about 1 percent per annum), "outlet substitution bias" (the bias resulting from the inappropriate treatment of a gradual shift to lower price stores), and most remarkably, the "logarithm bias". The last bias is caused by the practice of recording a decline in price from, say $\$ 2$ to $\$ 1$ as a 50 percent decline, and a subsequent increase to $\$ 2$ as a 100 percent rise. The price of the good would be shown as having risen 50 percent, even though it has not changed. Fach of the last two sources are estimated to account for a bias of 0.3-0.4 percent per annum. (I am indebted to Robert $J$. Gordon for discussion of this point.) 
achieve a measured inflation rate of zero when true inflation would at that point be significantly negative. 50

These arguments suggest that a positive though low target rate of inflation, around 1-3 percent, would be optimal. This is in practice the range that the Bundesbank has set for itself over the years, and it is similar to the ranges specified by both the Reserve Bank of New Zealand and the Bank of Canada in recent years. 51

The issue of a target price level versus target inflation rate nonetheless remains. Compare the goal of being close to a target price level that is growing at 2 percent per annum from a given date, say January 1995, with the goal of achieving a 2 percent inflation rate each year from 1995 on. The argument about price level versus zero inflation targeting is easily reformulated to apply to this case. With a target price path, the monetary authority attempts to offset past errors, thus creating more uncertainty about short term inflation rates than with an inflation target. The gain is more certainty about the long-term price level. My present view is that the inflation target with its greater short-term inflation rate certainty is preferable, despite its greater long-term price level uncertainty.

50 Duguay (1993) states that the measurement bias in Canada is only 0.5 percent per annum.

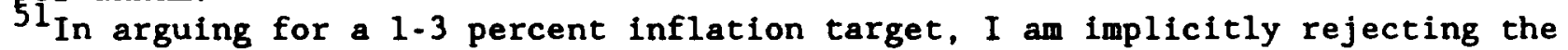
view that a reduction in the inflation rate from 3 to 1 percent would increase the growth rate of output by any significant amount. The regression results above do not address the relationship between inflation and growth at very low inflation rates. And in the presence of downward price inflexibility, there is reason to belleve that growth would be lower at very low inflation rates. 
v Dynamic Inconsistency and Inflationary Bias

Inflation in most of the G-7 countries ratcheted up in the $1960 \mathrm{~s}$ and 1970s. In the four business cycles completed in the United states between 1960 and 1981 , the average inflation rate rose from 2.8 percent to 9.9 percent. By the end of the 1970s, the inflation rate in the United states, like that in France, the United Ringdom, Italy and Canada was higher than any conceivable account of the costs and benefits of inflation could justify. No wonder that economists felt called upon to explain the apparent inflationary bias of economic policy.

Before we proceed, it is worth asking for a moment whether there is indeed an inflationary bias to economic policy. The simple answer is yes: inflation in most countries has exceeded the optimal rate of $1-3$ percent. It was not always thus: at the ends of the Napoleonic and Civil wars, and after World War I, Britain and the United states disinflated to get back to fixed gold parities. Certainly after World War I, this was not a wise policy and the disinflationary bias of monetary policy would have had to be explained.

The price level was stable for nearly a century until 1914, and it is only in the era of fiduciary money that the inflationary bias has emerged in most countries.

The most obvious explanation for an inflationary bias in economic policy is seigniorage. As already discussed, inflation is a tax, and under certain conditions, could be used in an optimal fiscal program. But because the tax is not an explicit one, it tends to be used to excess: in Keynes's (1924, p46) much quoted words,

A Government can live for a long time, even the German Government or the Russian Government, by printing paper 
money. ... The method is condemned, but its efficacy, up to a point, must be admitted. A Government can live by this means when it can live by no other. It is the form of taxation which the public finds hardest to evade and even the weakest Government can,enforce, when it can enforce nothing else.

Selgniorage helps explain why inflation is on average higher in countries with less developed tax systems than in those that succeed in collecting taxes. The inflation tax is also central to the analysis of hyperinflations. But because seigniorage revenues in the major industrialized countries are relatively small as a share of GNP, 52 and perhaps because of the institutional separation between the Treasury and the central bank (the inflation tax rate is not set in the budget), seigniorage appears not to receive explicit weight in the policy calculus that produces the inflation rate. 53

The fiscal aspects of inflation should nonetheless be taken more seriously as a source of inflationary bias. Inflation tax revenues of course constitute a larger share of tax revenues than of GNP; in the 1960s and 1970s, selgniorage accounted for more than six percent of tax (including seigniorage) revenues for several of the industrialized countries. Seigniorage considerations could help account for the increase in inflation during the 1960s and 1970s as government spending and taxes in general increased during that period. Further, a broader concept of the inflation tax, one that includes the gains that governments receive from unindexed tax brackets, and--

\footnotetext{
52 For most industrialized countries, seigniorage revenue, defined as the real value of the increase in the stock of high-powered money, is less than one percent of GNP. For a few countries, including Italy in the 1970s, it sometimes amounts to more than three percent of GNP.

53 Nor, as argued above, should it receive much weight in a country with a sophisticated tax system.
} 
if the inflation was unanticipated--from the devaluation of nominal government debt, renders the inflation tax explanation for an inflationary bias more plausible, especially if the inflation is unanticipated.

Nominal interest rate targeting provides a related explanation for the inflationary trends of the 1960 s and 1970s. If monetary policy targets the nominal interest rate, and has no nominal anchor--that is, no monetary or price level target to tie down the price level--then the price level becomes indeterminate, and may move in any direction, including upwards at an increasing rate. The explanation appears straightforward: the central bank automatically accommodates any shock to money demand, including for instance one arising from an increase in output that tends to raise inflation through the Phillips curve, or an increase in the expected inflation rate. In so doing it may validate the original shock. However, this argument encounters difficulties on closer examination. Formally, it can be shown that nominal interest rate targeting may produce an indeterminate inflation rate if inflation expectations are adaptive, but will not do so if expectations are rational. More important, combining any nominal anchor with a nominal interest rate target keeps the price level determinate. 54 To put the same point less formally, a central bank that keeps its nominal interest rate constant no matter what, may produce an accelerating inflation; a central bank that raises the target nominal rate when inflation increases, need not suffer the same fate.

It is a third explanation of inflationary bias that forms the basis of most recent models of central bank independence. That is the notion of

\footnotetext{
54 See Blanchard and Fischer (1989, pp577-580) on nominal interest rate targeting; the argument traces back to Wicksell ([1898] 1965) and was developed by Friedman (1968).
} 
dynamic inconsistency. Dynamic inconsistency is the inconsistency between the optimal policies that a policy authority would announce if its announcements were believed by the public, and the'policies the authority would carry out once the public had acted on the basis of those expectations. The simplest example of dynamic inconsistency arises in the case of capital taxation. In order to encourage growth, the government should promise to tax capital at a low rate. But once the capital is in place, the government is tempted to tax it, promising all the while that this will not happen again. In the case of inflation, the government will announce that it is committed to fighting inflation. If the private sector responds by signing contracts that embody a low expected rate of inflation, the central bank is tempted to produce higher output through surprise inflation. But in a rational world, the private sector will understand the temptations that face the monetary authority, and discount its pronouncements accordingly.

Equiliorium in this game theoretic model, due to Kydland and Prescott (1977) and Barro and Gordon (1983), occurs at that point where the inflation rate is sufficiently high that the marginal cost of higher (surprise) inflation is just equal to the marginal benefit of the lower unemployment it will produce. But this equilibrium inflation rate is higher than it needs to be. It is too high because output is at the same level (the natural rate) as it would be at a lower inflation rate. All that keeps inflation from being lower is the central bank's inability credibly to promise not to create surprise inflation at lower inflation rates-to precommit, in the language of game theory. Any device or institutional change that persuades the private sector that the government will not create surprise 
inflation at lower inflation rates will reduce the equilibrium inflation rate. 55

The tension between the direct benefits of lower inflation and the benefits of surprise inflation 56 that lies at the heart of these models is fundamental to modern analyses of monetary policy in general and central banking in particular. The model provides not only the basis for a theory of the role of monetary policy, but also a clear definition of credibility: a policy is credible when the private sector believes it will be carried out, and when it is correspondingly in the interest of the public sector to carry out the policy once the private sector has acted on its beliefs. Equivalently, a policy is credible if it is not dynamically inconsistent. The term credibility is of course used less precisely in other contexts: for instance, a central bank is said to be credible if its announcements are believed. 57

In practice, societies find ways of dealing with dynamic inconsistency. Despite the temptations of taxing capital in place heavily, just once, capital levies are rare. Some countries had low inflation rates

55 In his important work on the modern theory of central banking, Cukierman (1992, Chapter 2) offers four reasons for an inflationary bias: the employment or short-run Phillips curve motive, a fiscal revenue motive, interest rate smoothing, and a balance of payments motive (under fixed exchange rates). Cukierman emphasizes those motives that lead to dynamic inconsistency, whereas the argument here treats the revenue motive as a potentially separate cause of inflationary bias.

${ }^{56}$ These benefits include both the higher output available through the Phillips curve and the fiscal gains discussed above.

57 This is close to the formal definition, since announcements will not continue to be believed if they are inconsistent with reality. The more general informal definition goes beyond that emerging from the formal analysis, because it allows for credibility about policy announcements and decisions that were not anticipated at the time the private sector was making its decisions. 
well before the notion of dynamic inconsistency was formalized. The patent system deals with a similar problem in the creation of knowledge. 58

An independent central bank is one of the mechanisms that can deal with the Inflationary bias of monetary policy.

\section{Rules, Discretion and Central Bank Independence}

Kydland and Prescott (1977) and Barro and Gordon (1983) saw their demonstration of the inflationary bias of discretionary monetary policy as making the case for a monetary rule, along Friedman lines. With a monetary rule firmly in place, the central bank would not be able to create surprise inflation, and the problem of dynamic inconsistency would disappear. However a monetary rule is a far cry from an independent central bank.

Friedman's (1959) argument for a constant growth rate of money rule, based on the potentially destabilizing effects of active monetary policy when its effects have long and variable lags, may have led to the view that a money rule must be a constant growth rate rule. But activist feedback monetary rules are possible. The Barro-Gordon argument for a money rule would carry over to a model in which there is a potential role for an active monetary policy in offsetting shocks, thereby helping to stabilize at least inflation and perhaps also output. Given the structure of the economy, the optimal monetary feedback rule could be legislated into place and dynamic inconsistency and its inflationary bias would be prevented. 59

58 In this case, incentives have to be provided for the creation of new knowledge, but it is in society's interests to allow the general use of the knowledge once it has been created.

59 Friedman's (1959) argument for a constant growth rate rule is formally independent of the problem of dynamic inconsistency or the inflationary bias of monetary policy; rather, the argument is that there is no feedback in the optimal feedback rule. 
More sophisticated monetary feedback rules that take account of changes in the velocity of circulation have been proposed. For instance, McCallum (1994) proposes a rule that'sets the growth rate of the money base at 3 percent per annum, with adjustments for the change in base velocity over the past four years 60 and also for the deviation of nominal GNP from a target path. This rule is shown to produce good inflation and output performance in several small econometric models.

Note that there are two different arguments for a monetary rule in preference to discretionary monetary policy. Friedman's view is that policymakers not bound by a constant growth rate rule would be tempted into excess activism, destabilizing rather than stabilizing the economy. Barro and Gordon argue that discretionary policy has an inflationary bias, but do not dispute the possibility of a stabilizing activist feedback policy. Once the latter possibility is admitted, the case for a monetary rule--a rule that rigidly prescribes the behavior of a monetary aggregate--must rest on dynamic inconsistency. But there is then a tradeoff between the benefits of avoiding the inflationary bias of discretionary policy and the potential cost of being bound to follow a monetary rule that is no longer appropriate.

Goodhart's law and much recent experience suggest that any monetary rule will eventually break down; in the words of Richard Sayers (1958, p7), "we are doomed to disappointment if we look for rules applicable to all times and all places." The money demand instability manifested in many countries in the 1970s and 1980s, and in Germany in the last year, has put paid to the notion of relying on any simple monetary feedback rule, much less to

$60_{\mathrm{McCa}}$ lum states that a four year period is used to avoid adjusting for cyclical changes in velocity. 
legislating such a rule into existence. There cannot be a case now for dealing with the problem of dynamic inconsistency by putting in place any rule that prescribes by a fixed formula the growth rate of any monetary aggregate or the behavior of interest rates. Rather, the monetary authorities need to be given some flexibility to decide on day to day monetary policy. In this context, rules of the McCallum type can provide a useful benchmark against which to judge policy.

A fixed exchange rate peg is a form of monetary rule, one that leaves very little room for discretionary policy if the peg is taken seriously. A country that pegs to a reasonably stable currency can solve its inflationary problem. But exchange rate pegging is not danger-free: because non-traded goods prices can increase relative to traded goods prices, countries that peg frequently find themselves with overvalued currencies. In any fixed exchange rate system, the key countries need to find a way of solving their own inflationary bias problem. And as the experience of the Bretton Woods system and the European Monetary System shows, sometimes the key country acts in a way that makes it impossible to maintain the peg. ${ }^{61}$ Because the fixed versus flexible exchange rate issue has been extensively investigated, and because the need remains to set overall monetary policy within a fixed exchange rate system, I shall not continue the discussion of the fixed exchange rate regime.

To retain flexibility in monetary policy while dealing with the inflationary bias of discretionary policy, Rogoff (1985) proposed the

61 Fixed exchange rates within a monetary union are potentially different from fixed exchange rates among countries whose central banks can make independent monetary policy decisions. 
appointment of a conservative central banker, who is more averse to inflation than is society as a whole. 62 The central banker's aversion to inflation reduces the average inflation rate, but he still has the discretion to conduct stabilizing countercylical policy.

There are two important points about the solution in the Rogoff model. First, it represents a tradeoff between the reduction in the average inflation rate and the increase in the variability of output (relative to that attainable under a socially optimal policy) that is implied by the conservatism of the central banker. Second, there is an optimal degree of inflation aversion on the part of the central banker, which means that the central banker can be excessively inflation averse.

Rogoff's model provides one rationalization for an independent central bank. The bank is given the independence to pursue activist policy, but it is expected to be more inflation averse than is society. Central banks that are given strong powers and a mandate to secure price stability, perhaps "within the framework of the Government's overall economic policy", 63 seem to fit the Rogoff model. Based on this model, the convention has developed in empirical work of calibrating the independence of the central bank by the weight it places on inflation relative to output in its objective function. 64 By this measure of independence, a central bank can be too independent by being too monomaniacal about inflation.

\footnotetext{
62 Formally, both the central banker and society are assumed to prefer inflation and output levels that are close to (the same) target levels, but the central banker weights deviations of inflation from target relative to output deviations more heavily than society does.

${ }^{63}$ The quote is from a translation of the 1993 Act on the Status of the Banque de France.

${ }^{64}$ This convention is followed, for instance, in Table 1.
} 
Lohmann (1992) extends the Rogoff rule to allow the conservative central banker to be overruled by the government, at a cost. This produces a non-linear rule in which the central'bank responds proportionately more strongly to large than to small disturbances, in such a way such that the government never actually overrules the bank. 65 The outcome under this rule is better than that under the simple Rogoff rule.

One of the reasons for central bank independence is to remove the inflation tax from the control of the fiscal authority. Debelle (1994a) extends the Rogoff model to add a fiscal authority, which puts more weight on government spending than does the central bank or society. The central bank is responsible for setting the inflation rate, but the government receives the seigniorage revenue. Debelle shows that the inflation rate will be higher the greater the weight the government puts on its spending. Extending these results, Debelle and Fischer (1994) show that the inflation rate tends to be higher when the fiscal authority makes its decisions before the central bank. 66 Inflation is also likely to be higher in a situation of fiscal dominance, when the fiscal authority chooses the deficit and forces the central bank to finance it. This is a situation in which the central bank has no effective independence.

Models that include the possibility of developing a reputation present an alternative way out of the dynamic inconsistency problem. With a

65 This result fits with experience in countries such as Canada and the Netherlands where the government has the right to overrule the central bank but has to publish its reasons for doing so--and has not so far exercised its option.

${ }^{66}$ Technically, the assumption is that the fiscal authority acts as a Stackelberg leader, moving first, but taking into account the central bank's response to its choice of policy variables. 
sufficiently long horizon, and a sufficiently low discount rate, the monetary policymaker may find it optimal to develop a reputation for anti-inflationary zeal by pursuing the dynamically consistent low inflation policy. 67

The most important recent development in the game theory approach to monetary policy has come from applications of the principal-agent model. In this model, a principal (society) with well-defined goals has to design a contract that will motivate an agent (the central bank) to act in the principal's interests. In general the agent has access to some information that the principal does not.

Walsh (1993) and Persson and Tabellini (1993) have shown that a contract between the government and the central banker in which the central banker's remuneration declines in proportion to inflation can attain the first best equilibrium. ${ }^{68}$ Not only does this contract remove the inflationary bias of monetary policy, but the central bank's countercyclical policy is optimally active. Accordingly, appointing a central banker who has the same loss function as society, and penalizing him or her by an amount proportional to the inflation rate, enables society to obtain the first best solution. 69 This result is based on the assumption that the central bank has the same loss function as society, and that the only problem that the contract has to deal with is the inflationary bias resulting from dynamic inconsistency.

67 Several reputational models are discussed in Fischer (1990).

68 One example of such a contract occurs when the salary of the governor is fixed in nominal terms during his or her term of office, as for the Bank of England and the Reserve Bank of New Zealand.

${ }^{69}$ This result is obtained by Walsh (1993) and also by Persson and Tabellini (1993). Walsh shows that the first best can also be obtained by penalizing the central bank by an amount proportional to the money stock--which is stochastically related to the inflation rate. 
The target inflation rate in this contracting approach should be made to depend on any shocks that affect the optimal dynamically consistent inflation rate. This is done in both Canada and New Zealand, where a formula is provided to adjust the inflation target if there are supply shocks, and if indirect taxes are imposed.

Walsh and Persson-Tabellini assume that the contract will be carried out. Of course, the principal faces the temptation to behave in a dynamically inconsistent way by changing the contract ex post. The model therefore carries an implicit assumption that it is costly to change the contract.

The targeting approach to monetary policy that emerges from the contracting model has been implemented in New Zealand and Canada. It contrasts with the approach taken in Germany and in the new statutes of the Banque de France, where the central bank is given a more general mandate for price stability. Both the Reserve Bank of New Zealand and the Bundesbank are described as independent, but they differ in the degree of independence they have to specify short-run policy goals. The Bundesbank decides on its own on the inflation path it seeks to attain, while the Reserve Bank of New Zealand has to negotiate a target path with the government. Each central bank has full independence or discretion about the monetary policy tactics it follows to achieve these goals.

Because the term independence is not precise, some prefer to describe a central bank as autonomous, 70 or "somewhat apart from government". 71 Rather than fight the inevitable, I shall continue to use the ${ }^{70}$ See for instance the evidence by Charles Goodhart in The Role of the Bank of England, Volume II, paragraph 3.

TIFreedman, 1993, p91. 
term independence, but draw a distinction between goal independence and instrument independence. A central bank whose goals are imprecisely defined has goal independence: at an extreme, one could imagine endowing a central bank with the power to conduct monetary policy and giving it the goal of doing good. At the other extreme, the goal may be as precisely specified as those in New Zealand, where there is no goal independence. A central bank with a mandate for price stability but no numerical targets has more goal independence. A central bank has instrument independence when it has full discretion and power to deploy monetary policy to attain its goals. A central bank bound by a monetary rule would not have instrument independence, nor would a central bank which was required to finance the budget deficit.

The concept of accountability can be addressed within the contracting approach. The general notion of accountability is that there be adverse consequences for the central bank or the central banker of not meeting targets. In the optimal contract, the central banker is responsible for achieving the target inflation rate, and is penalized for failing to do so. While the penalty in the formal models appears to be monetary, public obloquy would serve as wel1. ${ }^{72}$ Thus even a central bank with a more general mandate could be held accountable, for instance by being required to publish a monetary policy report, or through public hearings on its performance such as the Humphrey-Hawkins hearings at which the Chairman of the Fed testifies twice a year. A central bank that is not held accountable is more likely to behave in a dynamically inconsistent way than an accountable bank--indeed any organization that is not accountable is likely to perform worse than one that is accountable.

72 As Persson and Tabellini (1993) point out, the announcement of targets, for money or inflation, makes sense as a device to help ensure accountability. 
A subsidiary question is to whom the central bank is accountable:

who is to judge whether targets were met, and to take the specified actions if they were not met. The answer implicit in the contracting approach is whoever makes the contract with the central bank. The more general answer is that the central bank should be accountable in some public forum, preferably to wellinformed elected officials. An important reason to expose central bankers to elected officials is that, just as the latter may have an inflationary bias, the former may easily develop a deflationary bias. Shielded as they are from public opinion, cocooned within an anti-inflationary temple, central bankers can all too easily deny--and perhaps convince even themselves--that there is a short-run tradeoff between inflation and unemployment, and that cyclical unemployment can be reduced by easing monetary policy.

Another subsidiary question is who in the central bank should be accountable. The answer must be primarily the Governor. It would also be possible to penalize the entire board for failing to meet targets, by reducing their pay. For instance, by fixing their salaries in nominal terms for the length of their tenure. 73

There is an interesting contrast between the accountability of the Bundesbank and the planned European Central Bank and that of the Fed or the Reserve Bank of New zealand. The Bundesbank is not formally accountable to any other body, whereas the Fed is. The Bundesbank arrangement, where the policy goal is not precise, and there is no formal accountability, poses a potential danger: there is very little to prevent it from pursuing a socially $\overline{7} \overline{3}$

As was pointed out in New zealand, this contract would not survive a protracted deflation, since the central bankers would then be seen as benefitting from the misery that was being inflicted on the rest of the country. 
excessive anti-inflationary policy. While the Bundesbank holds regular press conferences, these events are not the right forum to probe the basis of monetary policy. In practice, the Bundesbank has been very careful to take public opinion with it, and to publish a serious Monthly Report, but the danger remains.

Before turning to the empirical evidence on central bank independence, I want to reemphasize the fact that every central bank continually faces the short-run tradeoff between inflation and output. To illustrate, by 1991 the Bundesbank knew that it faced rising inflation. It could at that point have tightened money and raised short term interest rates to, say, 15 percent. Such a decision would have prevented some of the subsequent inflation, at a cost in terms of forgone output. Instead it chose to fight the inflation more gradually. In the fall of 1993, it faced another decision, of whether to cut interest rates more rapidly, tending to increase output but at the cost of a slower decline in the inflation rate. It chose not to cut interest rates rapidly, thereby disinflating more rapidly at the expense of slowing the recovery.

The Bundesbank's policy mandate to maintain the value of the currency is a far from complete guide to the crucial policy choices it has to make. Nor is a price stability mandate a sufficient guide for any central bank. That is why central banks cannot merely be given the task of keeping inflation low: accountability for their performance is important as well, especially their counter-cyclical performance, to be asked whether they are making the right judgment about the speed at which to reduce inflation, or to return to full employment. They cannot take refuge in the claim that there is no long-run tradeoff. Again quoting Keynes (1924, p88) 
Economists set themselves too easy, too useless a task if in tempestuous seasons they can only tell us that when the storm is long past the ocean is flat again.

VII. Empirical Evidence on Central Bank Independence (CBI).

There are several empirical measures of legal central bank independence $(C B I)^{74}$. I use the Grill1, Masciandaro and Tabellini (1991) or GMT index, calculated for 18 industrialized countries as a simple sum of 15 different legal provisions, grouped under five headings: appointments; relationship with government; constitution; monetary financing of the budget deficit; and monetary instruments. Under appointments, the central bank is more independent if the government does not appoint the governor, the longer the term of the governor, and so forth. Two provisions appear under the constitution heading: whether there is a statutory requirement that the central bank pursue monetary stability among its goals; and whether there is any legal provision that strengthens the hand of the central bank in disputes with the government. There are also two criteria under the monetary instruments head: whether the central bank sets the discount rate; and whether the central bank supervises commercial banks.

Figure 6 shows the key empirical result in this literature. For the period 1960-1992, there is a significant negative relationship between the average rate of inflation and central bank independence. 75

This relationship is very robust for the industrialized countries. But it does not extend to a larger sample of 72 countries examined in

74 See Cukierman (1992), Chapter 19.

75 The i-statistic on CBI in the regression line shown in Figure 6 is -4.6; $\mathrm{R}^{2}$ is 0.54 . 
Cukierman et al (1992). For these countries, those included in Table 1, there is a slightly positive relationship between inflation and legal CBI. For this group, Cukierman et al find that inflation is positively and significantly correlated with the rate of turnover of central bank governors. The contrast between the results for the industrialized countries and the larger group must be due to the difference between actual and legal independence. 76

The preceding analysis pointed most strongly to the central bank's mandate (lack of goal independence) and instrument independence as key factors in determining the inflationary bias of policy. To try to isolate these effects, I break down the GMT index of CBI into three components. 77 The first is the presence of a statutory requirement that the central bank pursue monetary stability among its goals; this is called INFOBJ. The second, EC6, consists of those measures relating to the central bank's right not to finance the government, and to set the discount rate. ${ }^{78}$ The third is a combination of legal provisions relating to appointments and the central bank's relationship with the government; this is called POL7.

Table 3 shows that the two variables most closely tied to inflation performance are INFOBJ and EC6. EC6, a measure of the central bank's ability to use its instruments freely, is the single variable most highly correlated

76 Cukierman et al (1992) also create a questionnaire-based index of CBI for 26 countries. The questionnaires were answered by central bank officials. The rank correlation between the legally and questionnaire based indexes was very low for the entire group, and a bit higher $(0.33)$ for the industrialized countries. 77 I draw here on Debelle and Fischer (1994).

78 GMT break their overall index down into a measure of political independence, which is (POL7 + INFOBJ), and one of economic independence, which is EC6 + the dummy variable that indicates whether the central bank supervises the commercial banks. 
with inflation. The variables grouped into POL7, which relate to appointment procedures, are not significantly related to inflation.

The most striking result of the empirical work is that CBI seems to have no adverse consequences. GMT (1991) and Alesina and Summers (1993) show that the improved inflation performance associated with increased CBI for industrialized countries does not come at a cost in terms of foregone growth. Similarly, for a cross-section of countries including LDCs, Cukierman et al (1993) find that while legal independence is negatively related to growth, the coefficient is not significant; an alternative (inverse) measure of central bank independence, the frequency of turnover of the central bank governor, is negatively related to growth (and positively related to inflation). Thus improved inflation performance does not seem to come at a cost in terms of lower growth.

Figure 7 shows the relationship between the variability of inflation and the variability of GDP growth over the period 1960-92, for the countries for which GMT have constructed measures of CBI. The association between these measures of variability is positive and significant, though the statistical significance disappears if Greece is excluded from the sample. 7980

These results could reflect either reverse causation from inflation aversion to CBI, or, closely related, the presence of a third factor that

79 Eijffinger and Schaling (1993) examine the relationship between alternative measures of CBI (Bade-Parkin (1988), Alesina (1988), GMT, and their own index) and inflation and output growth variability. They find that inflation variability is significantly negatively related only to the GMT index (in two out of three decades), and that output growth variability is not significantly related to any of the measures of CBI.

${ }^{80}$ The standard loss function in this literature penalizes deviations of the level of output from its target level, rather than the variability of output growth. Using measures of output deviations from linear and quadratic trends (of $\log$ output), we still find a positive but insignificant correlation between output and inflation variability. 
produces both economic stability and CBI. Cukierman et al (1992) have investigated the reverse causation issue econometrically and still find a negative correlation between inflation and CBI. Havrilesky and Granato (1993) include both measures of the extent of corporatism ${ }^{81}$ and the CBI index in a regression for the rate of inflation, and find that none of the measures of corporatism separately, or all of them together, enter significantly. By contrast, hall (1994) argues that centralized collective bargaining at the industry level (with IG Metall setting the pattern) is at least as much responsible for low inflation in Germany as is the independence of the Bunsdesbank.

The possibility of reverse causation is sometimes used to argue that the legal position of the central bank is hardly relevant to inflation performance: if a country is inflation averse, then it will have low inflation whatever the legal status of the central bank; if the country is not inflation averse, then the political system will always be able to get around the legal status of the central bank--as the results for the 72 country Cukierman et al (1992) sample establish. The implicit recommendation is that educating people about the costs of inflation is the best way of reducing inflation.

This is too extreme a position. In the first instance, the evidence on the costs of inflation and the relationship between inflation and growth suggests that countries benefit from being inflation averse. Even if reverse causation exists, it is probably optimal for those who want to reduce inflation to propose legislation setting up an independent central bank.

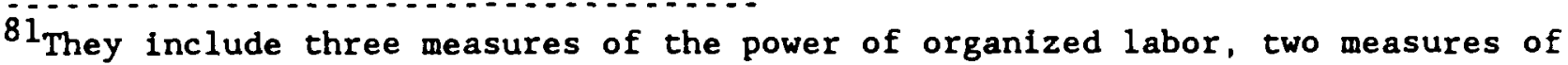
the leftward leaning of the government, and two measures of the size of the public sector. 
There can be no better way of forcing public opinion to think about the inflation issue. And, if the country is one in which the laws are obeyed, successful legislation will lead to a different monetary policy.

While the empirical results show the gains from central bank independence, there remains an important anomaly. The Rogoff model implies that we should find a negative relationship in Figure 7 if countries were being hit by the same shocks, and if the central banks were efficient but differed in their relative tastes for inflation and output variability. At least three factors could account for the positive relationship. If the variance of shocks differs systematically by country, then we would expect to find a positive relationship, with countries that are hit by bigger shocks ${ }^{82}$ having greater variability of both inflation and GDP growth. Or, if some central banks are more efficient than others, they would do better at stabilizing on both dimensions. Or, if more independent central banks are also more credible on inflation, they may obtain a "credibility bonus" which makes the economy respond more rapidly to monetary policy changes. 83

Most likely, the positive relationship between output and inflation variability in Figure 7 reflects both differences in the magnitude of shocks affecting different economies, and differences in the efficiency with which policymakers respond to those shocks. Countries with independent central banks are likely to be countries with more disciplined governments, and thus to suffer smaller self-imposed shocks. It is also likely that more

82 These shocks could be self-imposed, for instance greater variability of government spending.

${ }^{83}$ Kenneth Rogoff has pointed out that the relationship would also be positive if countries differ only in the wedge between the natural rate of unemployment and the socially optimal rate. 
independent central banks are more efficient: they are likely to have better research staffs, and more able and experienced decision makers. I suspect that the credibility bonus explanation would also receive strong support, but return to the issue below.

Despite Figure 7, I want to argue that, for the most sophisticated central banks, there remains a tradeoff between price level and output stability. Consider for instance Germany and the United States. Table 4 presents the mean inflation rates and growth rates, as well as the variability of inflation and growth ${ }^{84}$ for the United States and Germany for the period 1960-92. German inflation was lower than that of the United States over the period, and growth rates were the same. The United States has more stable output and less stable inflation. No doubt the United States could have had more stable inflation, if its central bank had been more devoted to fighting inflation. Should it have had such a central bank? While the empirical results on $C B I$ seem to say yes, since greater $C B I$ comes with lower inflation and no evident costs, the comparison with German performance suggests there is a tradeoff, and that countries have to decide how inflation averse they want their central bank to be.

We return now to the credibility bonus. In Figure 8 , we show the sacrifice ratio in recessions since 1962 against the GMT measure of central bank independence. ${ }^{85}$ The overall relationship is positive; it is also statistically significant. This implies that more independent central banks

${ }^{84}$ Similar results hold for the variability of output around linear or guadratic trends.

${ }^{85}$ This relationship was discovered independently by Adam Posen (1993). The output loss and inflation measures that underlie the sacrifice ratios are from Ball (1993). 
on average pay a higher output price per percentage point of inflation to reduce the inflation rate. A similar though weaker positive relationship holds between the output loss in recessions and central bank independence. 86

This result is consistent with the Phillips curve being flatter in low inflation than in high inflation economies. ${ }^{87}$ But it is nonetheless puzzling, because a more independent central bank should be more credible, and the public should more readily believe its anti-inflationary pronouncements. Figure 8 suggests that there is no credibility bonus in the labor markets for more independent central banks: they have to prove their toughness repeatedly, by being tough.

The evidence leaves little doubt that, on average, economic performance is better in countries with more independent central banks. The relationship between inflation and the elements of CBI is attributable mainly to the central bank's ability to use its policy instruments freely (instrument independence) and to the presence of a price stability goal (lack of goal independence). We further tentatively conclude that the causation in industrialized countries, where legal provisions are likely to have more force, runs at least in part from legal independence to lower inflation. As an analytic matter, we expect less price variability and greater output variability in countries with more independent central banks. Such a relationship is not visible in the aggregate data. The elements of a tradeoff are present in comparing United States and German data, and there must be such a tradeoff for an efficient central bank. Finally, central bank independence

${ }^{86}$ The t-statistic on the $\mathrm{CBI}$ measure is 3.8 in Figure 8 , and 1.96 when the output loss is regressed on CBI.

${ }^{87}$ See footnote 17 and the paragraph to which it is attached. 
does not appear to bring a credibility bonus in the labor markets: even independent central banks have to fight hard and long to bring inflation down after an inflationary shock has struck.

VIII. The Charter of a Modern Central Bank.

The case we have set out for an independent central bank is becoming increasingly accepted. Within the last decade, the central banks of Chile, France, Mexico, New Zealand, and Venezuela have all had their legal independence enhanced, and the Mastricht treaty requires national central banks participating in the European System of Central Banks to meet a prescribed standard of independence. And of course, there is a lively debate in Britain over the desirability of making the Bank of England, now explicitly subservient to the Treasury, independent. 88

The argument for greater independence for the Bank of England is based on three foundations. The first is the theoretical literature on the inflationary bias of discretionary policy-making. The second is the empirical literature on central bank independence. Closely related is the third argument for greater independence, the success of the Bundesbank and the German economy over the past forty years. The Reserve Bank of New Zealand's success in reducing inflation provides further support for independence. However, the New Zealand experience has come at a time of general disinflation, and it remains to be seen how well the Bank operates as worldwide Inflationary pressures build. 89

${ }^{88}$ See for instance Roll et al (1993), Vibert (1993), and House of Commons (1993).

89 Australia, whose central bank is much less independent than that of New Zealand, was almost as successful in disinflating as New Zealand; however inflationary expectations in New Zealand at the end of 1993 were more favorable than those in Australia. See Debelle, 1994b. 
The theoretical and empirical evidence presented here has shown that the following guidelines could be useful to central banks:

- A clearly defined mandate, which includes price stability. One example would be a low (1-3 percent) average rate of inflation.

- A public announcement of its intermediate-term policy goals; the announcement could describe the allowances that will be made for changes in the terms of trade, interest rates, and indirect taxes in judging whether the target has been met. 90

- Accountability in two senses: responsibility for meeting its announced goals; and the requirement to explain and justify its policies to the legislature and the public. Presumably the Governor of the Bank would testify in public on the performance of monetary policy in meeting its preannounced goals. Along with the testimony a publication of a report, along the lines of the Inflation Report. The most difficult issue is the sanctions that would be imposed on the Bank for failing to meet its targets. Sharp public questioning is the only sanction that is now applied in the U.S., and there is no explicit sanction in most countries. Public reprimand and loss of reputation is probably a sufficient sanction.

- Government authority to override the Bank's decisions, but with the override decision carrying a cost for the government. In New zealand, the government has the right to override the Bank's policy targets, by means of an order in

$$
\overline{\mathbf{9}} \overline{\mathbf{T}}
$$

The adjustments may take the form of using a special price index for measuring inflation, such as RPIX. See for example the Bank of England's Inflation Report, February 1994 , p5. 
Council that lasts no more than a year The more general Canadian provision whereby "the Minister of Finance, with the approval of...the Cabinet...may issue a directive to the Governor as to the monetary policy the Bank is to follow" 91 is one precedent. While the procedure seems to give the government an easy means of controlling the Bank, any contemplation of firing the Governor would take into account that most of the Board would remain in place, and that monetary policy could not therefore be easily manipulated by the government. At the same time, the threat of the use of the directive would give the Bank pause before it set out on a policy at odds with that of the government, thus providing a balance of power.

- Authority to set interest rates and other monetary policy variables in order to achieve its policy goals. In New zealand, the Bank has to agree on inflation targets with the government, but if a Bank only has to consult with the government in setting the inflation targets, it is given a slightly greater measure of independence, but one which is constrained by the override procedures. 92

-The financing of the government deficit, or management of the public debt left to some other branch.

\footnotetext{
92 The Role of the Bank of England, Volume II, p161.

92 It is sometimes claimed that the British parliamentary tradition makes it impossible to set up arrangements of the type discussed here. Countries with similar traditions, such as canada and New zealand, have done so successfully, and there is no reason Britain could not follow suit.
} 
-The responsibility for setting both interest rates and the exchange rate, so long as the exchange rate floats. If the government chooses a fixed exchange rate regime, it has then essentially--though not completely--determined monetary policy. While a central bank can be more or less independent of the government in a fixed exchange rate system, its independent ability to determine the rate of inflation and interest rates is sharply curtailed. 


\section{BIBLIOGRAPHY}

Alesina, Alberto (1988). "Macroeconomics and Politics", NBER Macroeconomics Annual, 13-51.

-...- and Guido Tabellini (1987). "Rules and Discretion with Non-Coordinated Monetary and Fiscal Policies", Economic Inquiry, 25, 619-630.

and Lawrence $H$. Summers (1988). "Central Bank Independence and Macroeconomic Performancs: Some Comparative Evidence", Journal of Money. Credit and Banking, 25, 2 (May), 151-162.

Bade, Robin and Michael Parkin (1988). "Central Bank Laws and Monetary Policy", Department of Economics, University of Western Ontario (October).

Bailey, Martin J. (1956). "The Welfare Cost of Inflationary Finance", Journal of Political Economy, 64, 2 (April), 93-110.

Ball, Larry (1993). "What Determines the Sacrifice Ratio?", NBER Working Paper, number 4306 .

-...., N. Gregory Mankiw and David Romer (1988). "The New Keynesian Economics and the Output-Inflation Trade-off", Brookings Papers on Economic Activity, $1,1-65$.

Barro, Robert J. and David Gordon (1983). "A Positive Theory of Monetary Policy in a Natural Rate Model", Journal of Political Economy, 91, 4 (Aug), 589-610.

Blanchard, Olivier (1986). "The Wage-Price Spiral", Quarterly Journal of Economics, 101, 3 (Aug), 543-565.

.... and Stanley Fischer (1989). Lectures on Macroeconomics. Cambridge, Mass: MIT Press.

..... and Lawrence H. Summers (1986). "Hysteresis and the European Unemployment Problem", NBER Macroeconomics Annual, 15-78.

Burns, Arthur F. (1978). Reflections of an Economic Policy Maker. Washington, DC: American Enterprise Institute.

Capie, Forrest, Charles Goodhart and Norbert Schnadt (1994). "The Development of Central Banking", mimeo, this conference. 
Caplin, Andrew and John Leahy (1991). "State-Dependent Pricing and the Dynamics of Money and Output", Quarterly Journal of Economics, 106, 3 (Aug), 683-708.

and Daniel Spulber (1987). "Menu Costs and the Neutrality of Money", Quarterly Journal of Economics, 102, 4 (Nov), 703-26.

Chari, V.V., Lawrence J. Christiano, and Patrick J. Kehoe (1991). "Optimal Fiscal and Monetary Policy: Some Recent Results", Journal of Money. Credit and Banking, 23, 3 (Aug, Part 2), 519-539.

Cooley, Thomas F. and Gary D. Hansen (1991). "The Welfare Costs of Moderate Inflation", Journal of Money. Credit and Banking, 23, 3 (Aug, Part 2), 483-503.

Cukierman, Alex (1992). Central Bank Strategy. Credibility, and Independence: Theory and Evidence. Cambridge, Mass: MIT Press.

-....., Steven B. Webb and Bilin Neyapti (1992). "Measuring the Independence of Central Banks and Its Effect on Policy Outcomes", World Bank Economic Review, 6, 3 (Sept), 353-398.

-...., Pantelis Kalaitzidakis, Lawrence Summers and Steven Webb (1993). "Central Bank Independence, Growth, Investment, and Real Rates", Carnegie-Rochester Conference Series on Public Policy, 39 (December), $95-140$.

Dawe, S. (1990). "Reserve Bank of New Zealand Act 1989", 奋eserve Bank Bulletin, 53, 1, 21-27.

Debelle, Guy (1994a). "Central Bank Independence: A Free Lunch?", mimeo, MIT (February)

..... (1994b). "The Ends of Three Small Inflations: Australia, New Zealand and Canada", mimeo, MIT (February).

...... and Stanley Fischer (1994). "How Independent Should a Central Bank Be?", mimeo, MIT, April.

de Kock, M.H. (1974). Central Banking, fourth edition. New York: St. Martin's Press.

Dornbusch, Rudiger and Stanley Fischer (1994). Macroeconomics, sixth edition. New York: McGraw Hill.

Driffill, John, Grayham E. Mizon and Alistair Ulph (1990). "Costs of Inflation", in B.M. Friedman and F.H. Hahn (eds), Handbook of Monetary Economics, Volume 2. Amsterdam: North-Holland.

Duguay, Pierre (1993). "Some Thoughts on Price Stability versus Zero Inflation", mimeo, Bank of Canada. 
Eijffinger, Sylvester and Eric Schaling (1993). "Central Bank Independence: Theory and Evidence", Tilburg University, The Netherlands, February.

Faig, Miguel (1988). "Characterization of the Optimal Tax on Money when It Functions as a Medium of Exchange", Journal of Monetary Economics, 22, 1 (July), 137-148.

Fischer, Stanley (1977). "Long Term Contracts, Rational Expectations, and the Optimal Money Supply Rule", Journal of Political Economy, 85, 1 (Feb), $163-190$.

.... (1981). "Towards an Understanding of the Costs of Inflation: II," in Karl Brunner and Allan H. Meltzer, (eds), The Costs and Consequences of Inflation, Carnegie-Rochester Conference Series on Public Policy, Vol. 15, North-holland, 5-42. (Reprinted in Fischer (1986).)

.... (1983). "Welfare Aspects of Government Issue of Indexed Bonds", in R. Dornbusch and M.H. Simonsen (eds), Inflation. Debt, and Indexation. Cambridge, Mass: MIT Press. (Reprinted in Fischer (1986).)

..... (1986). Indexing. Inflation, and Economic Policy. Cambridge, Mass: MIT Press.

-.... (1990). "Rules versus Discretion in Monetary Policy", in B.M. Friedman and F.H. Hahn (eds), Handbook of Monetary Economics, Volume 2. Amsterdam: North-Holland.

..... (1993). "The Role of Macroeconomic Factors in Growth", Journal of Monetary Economics, 32, 3 (Dec), 485-512.

..... and John Huizinga (1982). "Inflation, Unemployment, and Public Opinion Polls", Journal of Money. Credit and Banking, 14, 1 (Feb), 1-19. (Reprinted in Fischer (1986).)

and Franco Modigliani (1978). "Towards an Understanding of the Real Effects and Costs of Inflation," Weltwirtschaftliches Archiv, 114 , 810-32. (Reprinted in Fischer (1986).)

..... and Lawrence Summers (1989). "Should Governments Learn to Live with Inflation?" American Economic Review. Papers and Proceedings, 79 (May), 382-387.

Freedman, Charles (1993). "Designing Institutions for Monetary Stability: A Comment", Carnegie-Rochester Conference Series on Public Policy, 39 (December), 85-94.

Friedman, Milton (1959). A Program for Monetary Stability. New York: Fordham University Press.

(1968). "The Role of Monetary Policy", American Economic Review, 58, 1, (March), 1-17. 
.... (1969). "The Optimum Quantity of Money", in M. Friedman, The Optimum Quantity of Money and Other Essays. Chicago, Illinois: Aldine Publishing Company.

Grilli, Vittorlo, Donato Masciandaro and Guido Tabellini (1991). "Political and Monetary Institutions and Public Financial Policies in the Industrial Countries", Economic Policy, 13 (October), 341-392.

Hall, Peter A. (1994). "Central Bank Independence and Coordinated Wage Bargaining: Their Interaction in Germany and Europe", forthcoming, German Politics and Society.

Havrilesky, Thomas and James Granato (1993). "Determinants of Inflationary Performance: Corporatist Structures vs. Central Bank Autonomy", Public Choice, 76, 249-261.

Huizinga, John (1993). "Inflation Uncertainty, Relative Price Uncertainty, and Investment in U.S. Manufacturing", Journal of Money, Credit and Banking, 25, 3 (Aug, Part 2), 521-549.

Hume, David (1955). "Of Money", in D. Hume, Writings on Economics, E. Rotwein (ed). Madison: University of Wisconsin Press.

Jarrett, J. Peter and Jack G. Selody (1982). "The Producitivty-Inflation Nexus in Canada, 1963-1979". Review of Economics and Statistics, 64 (Aug), $361-367$.

Keynes, John Maynard (1924). Monetary Reform. New York: Harcourt, Brace and Company.

Kydland, Finn and Edward S. Prescott (1977). "Rules Rather than Discretion: The Inconsistency of Optimal Plans", Journal of Political Economy, 85,3 (June), 473-492.

Lohmann, Susanne (1992). "Optimal Commitment in Monetary Policy: Credibility versus Flexibility", American Economic Review, 82, 1 (March), 273286.

Lucas, Robert E. (1973). "Some International Evidence on Output-Inflation Tradeoffs", American Economic Review, 63, 3 (June), 326-334.

..... (1994). "On the Welfare Cost of Inflation", mimeo, University of Chicago.

McCallum, Bennett T. (1994). "Monetary Policy Rules and Financial Stability", National Bureau of Economic Research Working Paper No. 4692, April.

Mishkin, Frederic S. (1983). A Rational Expectations Approach to Macroeconomics. Chicago: University of Chicago Press.

Persson, Torsten and Guido Tabellini (1993). "Designing Institutions for Monetary Stability", Carnegie-Rochester Conference Series on Public 
Policy, 39 (December), 53-84.

Phelps, Edmund S. (1967). "Phillips Curves, Expectations of Inflation, and Optimal Unemployment Over Time", Economica, 34, 3 (August), 254-281.

.... (1972). Inflation Policy and Unemployment Theory. New York: Norton.

-... (1973). "Inflation in the Theory of Public Finance", Swedish Journal of Economics, 75, 1, 67-82.

Phillips, A.W. (1958). "The Relation between Unemployment and the Rate of Change of Money Wages in the United Kingdom, 1861-1957" Economica, 25, 4, (Nov), 283-299.

Posen, Adam (1993). "Central Bank Independence Does Not Cause Low Inflation: The Politics Behind the Institutional Fix", mimeo, Harvard University, December.

Reagan, Patricia and Rene M. Stulz (1993). "Contracting Costs, Inflation, and Relative Price Variability", Journal of Money, Credit and Banking, 25, 3 (Aug, Part 2), 585-601.

Rogoff, Kenneth (1985). "The Optimal Degree of Commitment to an Intermediate Monetary Target", Quarterly Journal of Economics, 100, 4 (November), $1169-1190$

Rol1, Eric et al (1993). "Independent and Accountable: A New Mandate for the Bank of England". London: Centre for Economic Policy Research, October.

Romer, Christina and David Romer (1989). "Does Monetary Policy Matter? A New Test in the Spirit of Friedman and Schwartz", NBER Macroeconomics Annual, $121-170$.

Rudebusch, Glenn D. and David W. Wilcox (1994). "Productivity and Inflation: Evidence and Interpretations", mimeo, Federal Reserve Board, Washington, DC, April.

Samuelson, Paul A. amd Robert M. Solow (1960). "Analytical Aspects of AntiInflation Policy", American Economic Review, 50, 2, (May), 177-194.

Sayers, Richard S. (1958). Central Banking After Bagehot, reprinted. Oxford: At the Clarendon Press.

Summers, Laurence H. (1991). "How Should Long-Term Monetary Policy Be Determined?", Journal of Money. Credit and Banking, 23, 3 (Aug., Part 2), $625-631$.

Sidrauski, Miguel (1967). "Rational Choice and Patterns of Growth in a Monetary Economy", American Economic Review, Papers and Proceedings, 71 (May), 534-544. 
Taylor, John B. (1981). "On the Relation Between the Variability of Inflation and the Average Inflation Rate", in Karl Brunner and Allan $\mathrm{H}$.

Meltzer, (eds), The Costs and Consequences of Inflation, Carnegie-

Rochester Conference Series on Public Policy, Vol. 15, North-Holland, $57-85$.

Tommasi, Mariano (1994). "The Consequences of Price Instability in Search Markets: Towards Understanding the Effects of Inflation", forthcoming, American Economic Review.

Vibert, Frank (1993). "The Independence of the Bank of England and the Maastricht Treaty". London: European Policy Forum, May.

Walsh, Carl (1993). "Optimal Contracts for Independent Central Bankers: Private Information, Performance Measures and Reappointment", Working Paper 93-02, Federal Reserve Bank of San Francisco, May.

Wicksell, Knut (1965). Interest and Prices. New York: Augustus M. Kelley. Reprints of Economic Classics. 
Table 1: CENTRAL BANK OBJECTIVES

Full Sample

\begin{tabular}{|c|c|c|c|c|}
\hline $\begin{array}{l}\text { Description } \\
-\end{array}$ & $\begin{array}{l}\text { Value of } \\
\text { Objective }\end{array}$ & $\begin{array}{l}\text { Number of } \\
\text { countries }\end{array}$ & $\begin{array}{l}\text { Percent of } \\
\text { total }\end{array}$ & $\begin{array}{l}\text { Industrial } \\
\text { Countries }\end{array}$ \\
\hline 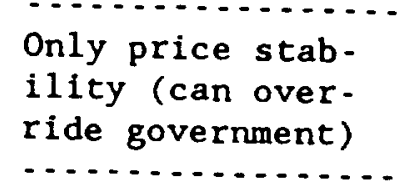 & 1 & 2 & 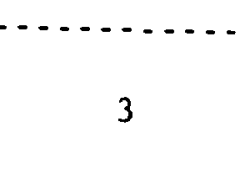 & Germany \\
\hline $\begin{array}{l}\text { Only price stab- } \\
\text { ility }\end{array}$ & 0.8 & 6 & 8 & $\begin{array}{l}\text { Finland, Greece } \\
\text { Ireland, Netherlands }\end{array}$ \\
\hline $\begin{array}{l}\text { Price stability } \\
\text { and compatible } \\
\text { objective }\end{array}$ & 0.6 & 17 & 24 & $\begin{array}{l}\text { Austria, Denmark, } \\
\text { Luxembourg, Spain. }\end{array}$ \\
\hline $\begin{array}{l}\text { Price stability } \\
\text { and incompatible } \\
\text { objectives } \\
\ldots . . .\end{array}$ & 0.4 & 22 & 31 & $\begin{array}{l}\text { Australia, Iceland, } \\
\text { New Zealand, U.S. }\end{array}$ \\
\hline No objectives & 0.2 & 10 & 14 & $\begin{array}{l}\text { Canada, Italy, } \\
\text { Sweden, U.K. }\end{array}$ \\
\hline $\begin{array}{l}\text { Objectives but not } \\
\text { price stability. } \\
0 . \ldots\end{array}$ & 0.0 & 15 & 21 & $\begin{array}{l}\text { Belgium, France, } \\
\text { Japan, Norway }\end{array}$ \\
\hline Total & & 72 & & 21 \\
\hline
\end{tabular}

Source: Cukierman et al, 1992, Table A.1. Data are for the 1980s. 
Table 2

\title{
THE REAL EFFECTS OF INFLATION
}

\author{
Nature of effect
}

Source of effect

Direct

Indirect

(general equilibrium)

\section{Fully indexed economy}

No interest paid on currency, a government (outside) liability

Need to change prices more frequently

1. Increase in government revenue (inflation tax)

2. Economizing on currency

3. Reduction in private net wealth

4. Resource costs of price change ("menu costs")
Gl Reduction in other taxes or increases in government spending G2 Diversion of resources to transactions (shoe-leather costs)

G3 Offsetting increase in capital stock, lowering real interest rate

G5 See G1

G6-10 Potential effects on cost of capital to corporations and inindividuals, with resultant effects on capital accumulation; changes in pattems of financing

G9 See also Gl

7. Reduction of net real cost of borrowing relative to pretax real rate

8. Return to equity holders in levered corporations rises given constant debt-equity ratios, constant real pretax interest rate on bonds, and constant marginal product of capital

9. Changes in government tax receipts; net effect depends on induced changes in pretax real interest rate on bonds, differences in tax rates between debtors (including corporations) and creditors

4. Depreciation at original cost 10. Return to equity holders declines

Costs of goods sold measured at 11. Tax revenue increases original costs

5. Taxation of nominal capital gains

Nominal accounting methods used by government
G10-11 See also G1 Combined effects vary among firms, depending on nature of assets; likely shift away from use of long-lived assets; shift in inventory accounting methods from FIFO to LIFO
12. Post-tax retum to equity owners on realized gains declines if pre-tax return remains constant 13. Lock in effects 14. Distortions in interpretations of economic situation, e.g., nominal interest share in GNP rises, savings rate misinterpreted since both income and savings measured incorrectly; overstatement of government deficit 


\section{Real effects of nominal private institutions and habits}

Continued reliance on nominal annuity contracts, mortgages

Nominal accounting methods

\section{Real effects of unanticipated inflation through existing nominal contracts}

Existing contracts for goods or services fixed in money terms or otherwise sticky

Existing debt contracts fixed in nominal terms
15. Declining real repayment streams relative to nominal streams

16. Distortion of reports of profits; other money illusions based on confusion between real and nominal interest rates possible quantity of services fixed by contract

18. Effects on quantity of services provided

19. Distortions of relative prices fixed at different times

20. Redistribution from private to public sector 21. Redistributions between private debtors and creditors

\section{Real effects of uncertainty of future inflation}

Need to make decisions without 22. Reluctance to make future commitments knowledge of future prices without knowledge of prices; absence of safe asset

23. Shortening of nominal contracts
G15 Possible effects on real interest rates, and therefore investment

G16 Effects on stock market valuation of firms; investment decisions

G17-19 Effects on level of economic activity (Phillips curve); Short-run functional income redistributions by income size

G19 Misallocations of resources arising particularty from need to search for relative price information G20 Ultimately intergenerational transfers

G22 Changes in patterns of asset accumulation

G23 Increased transaction costs of making frequent contracts, and loss of planning ability

G24 Shortages, possibly pervasive; misallocations of resources

G25 Instability of financial flows, with possible effects on direction and level of investment activity

\section{Real effects of government endeavors to suppress symptoms of inflation}

Public dissatisfaction over intlation, and governmental reactions

Government concem over potential bankruptcies and other financial losses resulting from a rise in interest rates
25. Control of interest rates, intervention in bond markets
24. Wage and price controls 


\begin{tabular}{|c|c|c|c|c|c|}
\hline Variable & (1) & (2) & (3) & (4) & (5) \\
\hline INFOBJ & $\begin{array}{l}-1.76 \\
(1.72)\end{array}$ & $\begin{array}{l}-2.28 \\
(1.61)\end{array}$ & $\begin{array}{l}-4.27 \\
(1.30)\end{array}$ & & \\
\hline EC6 & $\begin{array}{l}-1.02 \\
(0.55)\end{array}$ & $\begin{array}{l}-1.02 \\
(0.55)\end{array}$ & & $\begin{array}{l}-1.53 \\
(0.42)\end{array}$ & \\
\hline POL7 & $\begin{array}{l}-0.41 \\
(0.45)\end{array}$ & & & & $\begin{array}{l}-0.94 \\
(0.51)\end{array}$ \\
\hline$\overline{\mathrm{R}}^{2}$ & 0.44 & 0.44 & 0.37 & 0.42 & 0.12 \\
\hline
\end{tabular}

Dependent variable is mean inflation rate, 1960-1992. Data definitions in text. Standard errors in parentheses.

Table 4: INFLATION AND OUTPUT, UNITED STATES AND GERMANY

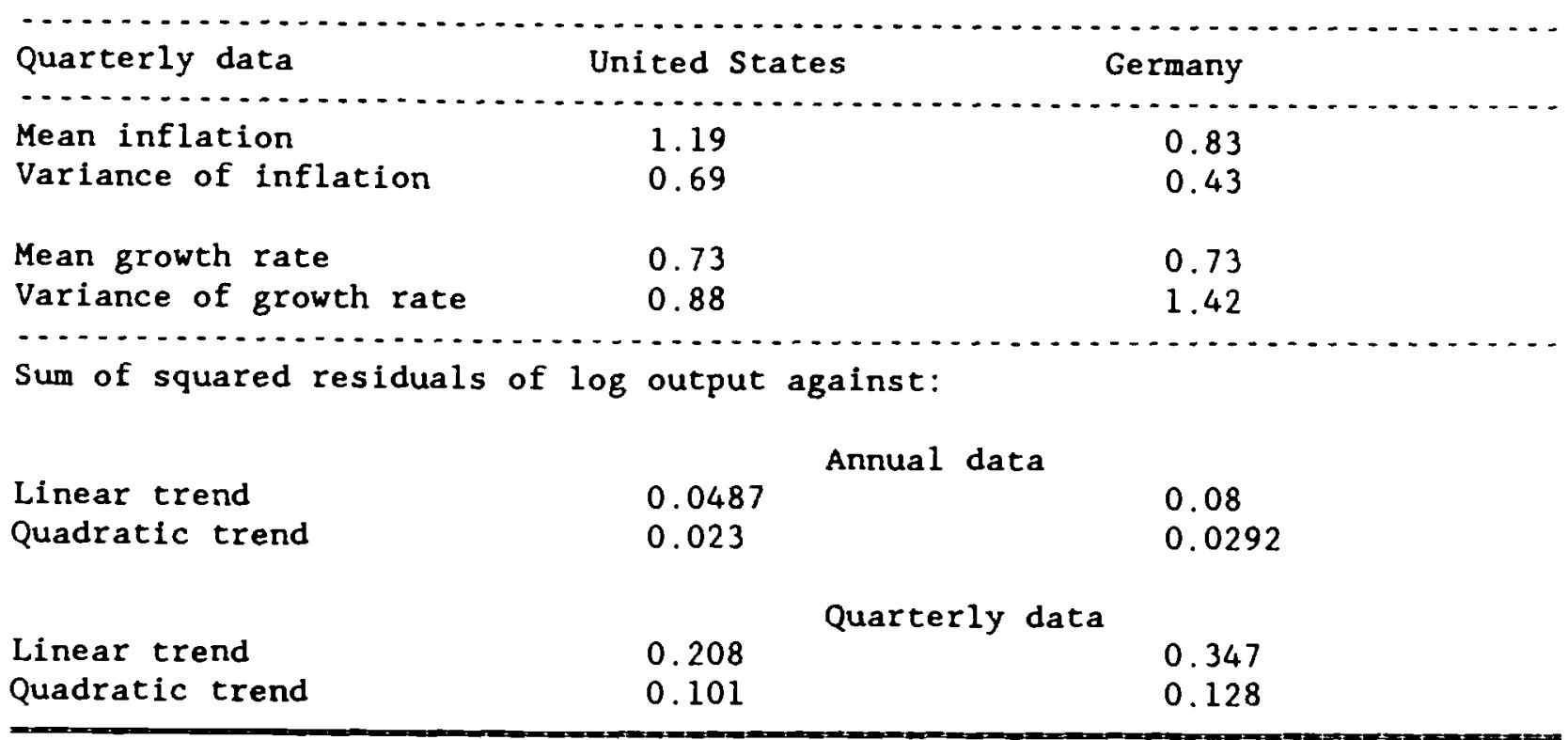

Data are for $1960-1992 / 3$. 


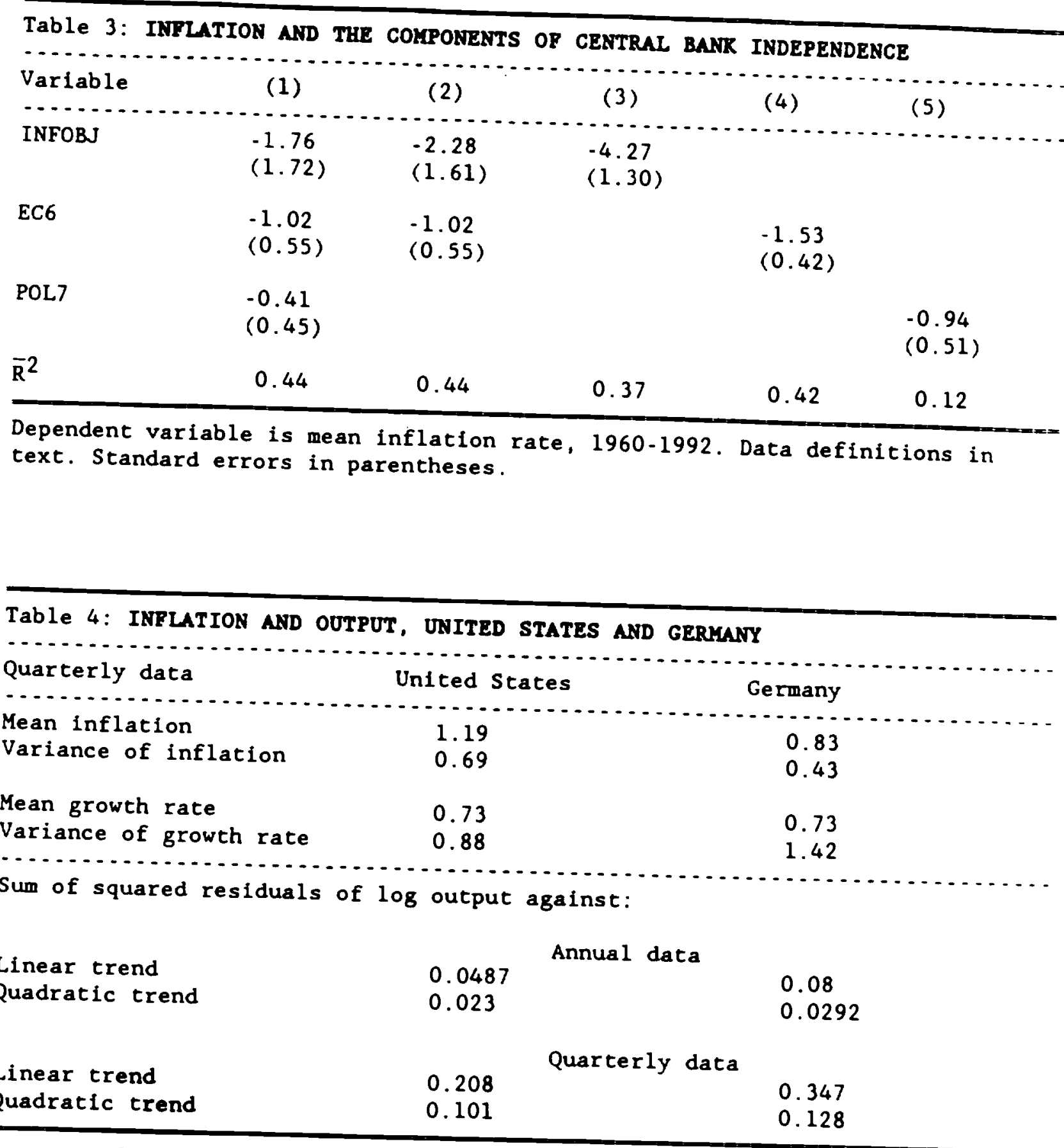

Data are for $1960-1992 / 3$. 


\section{Figure 1: Inflation and Unemployment US 1961-69}

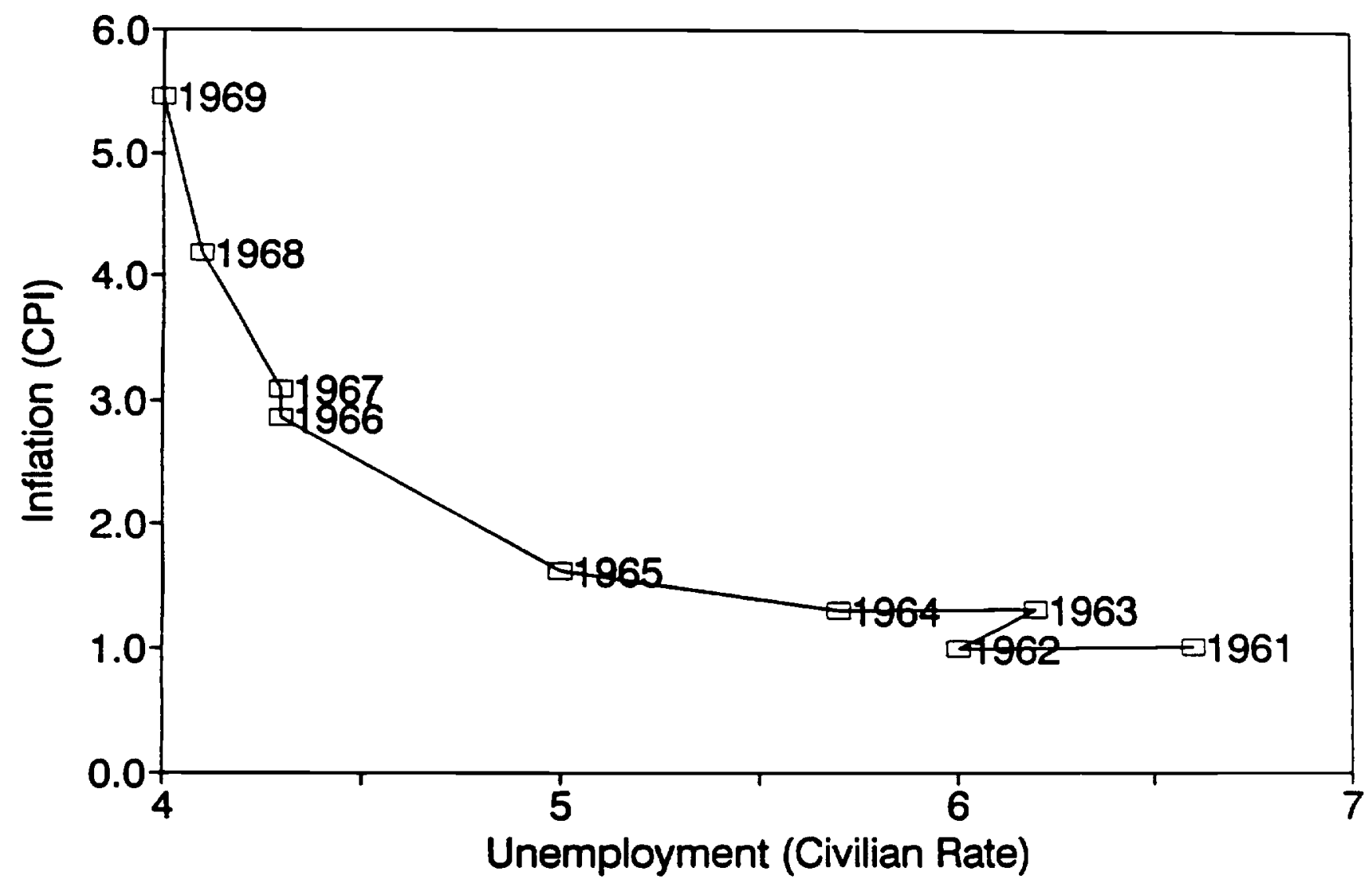




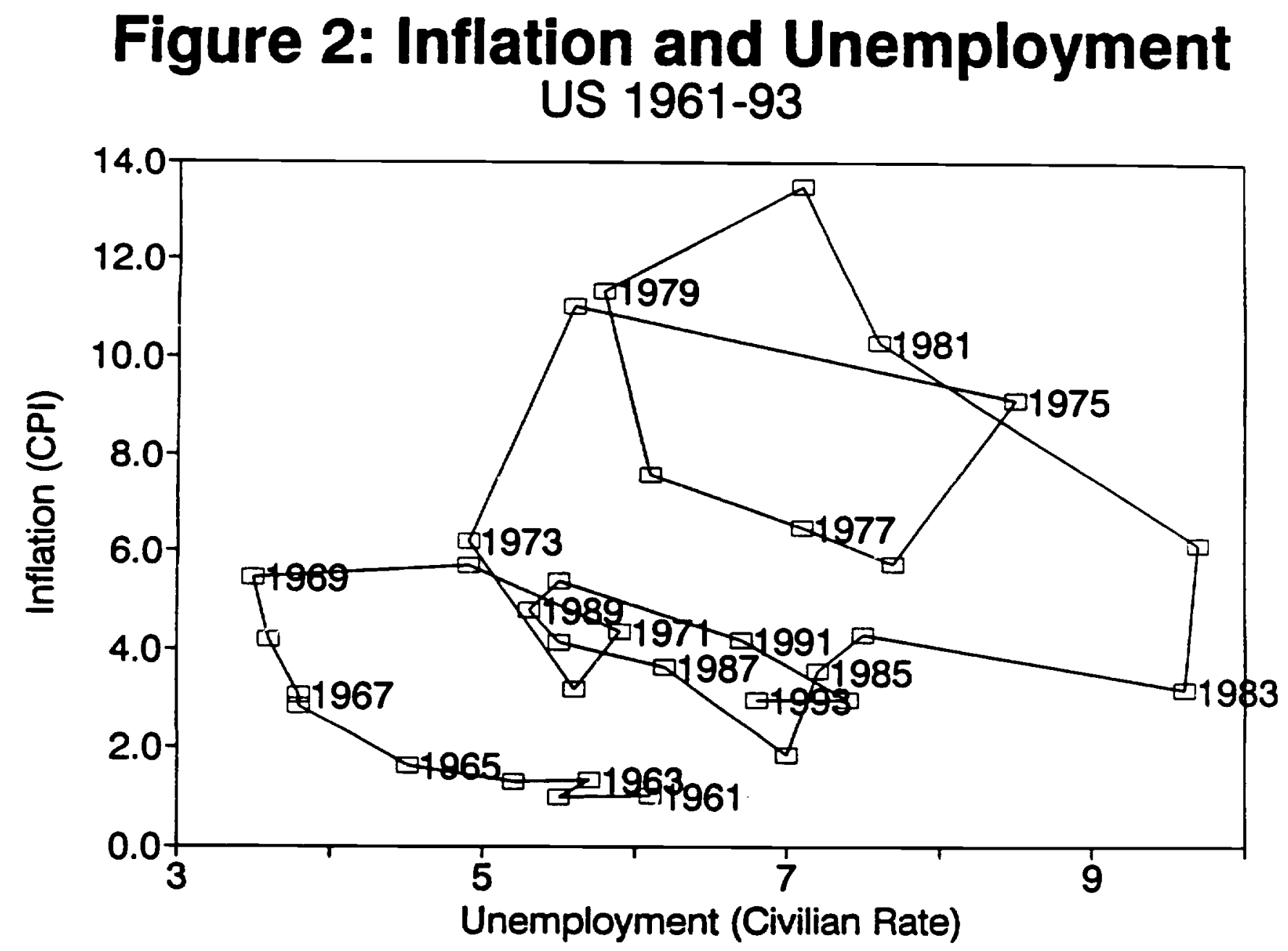




\section{Figure 3: Inflation and Productivity US 1953-92}

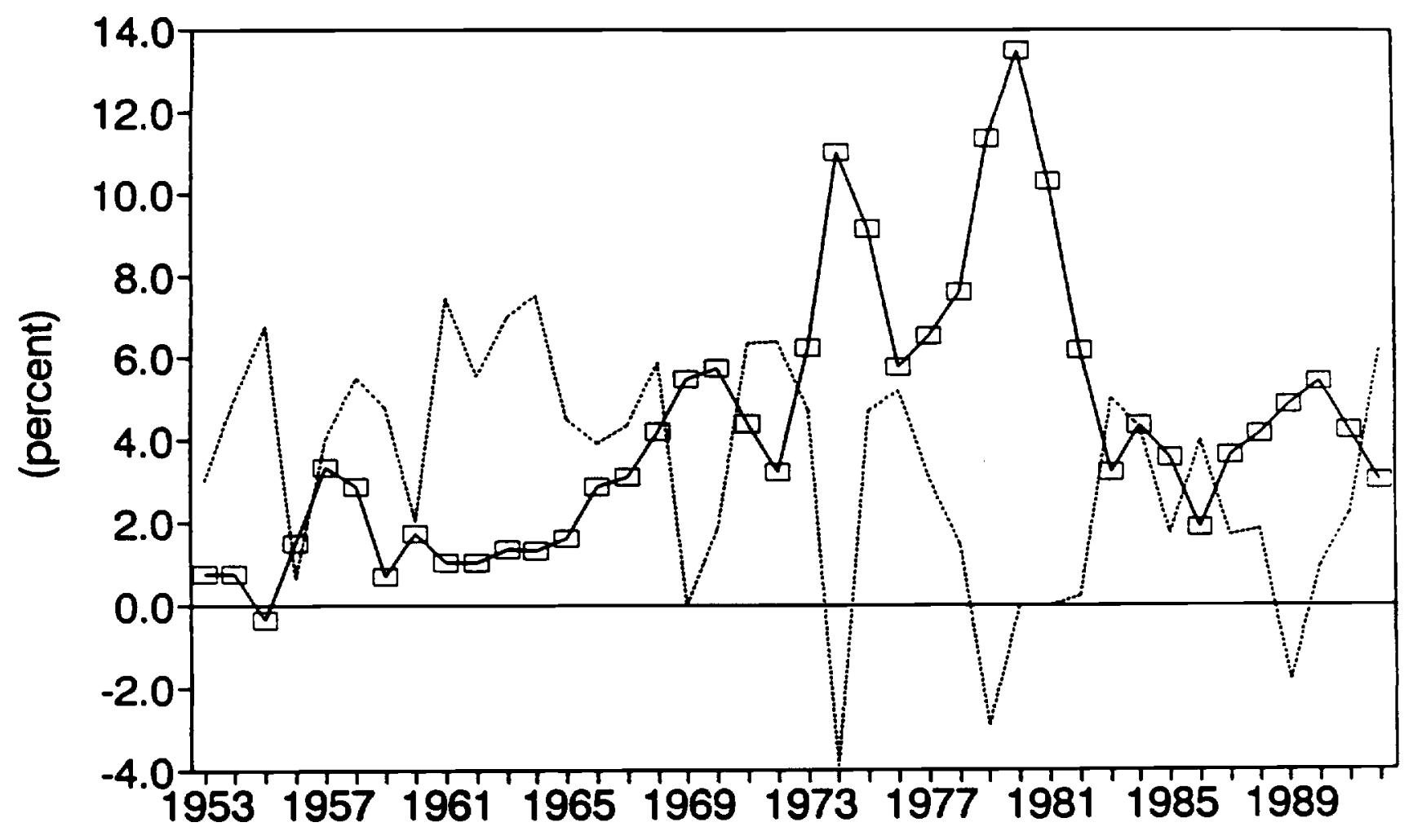

$\square-$ Inflation (CPI) $\quad$ Productivity Growth 


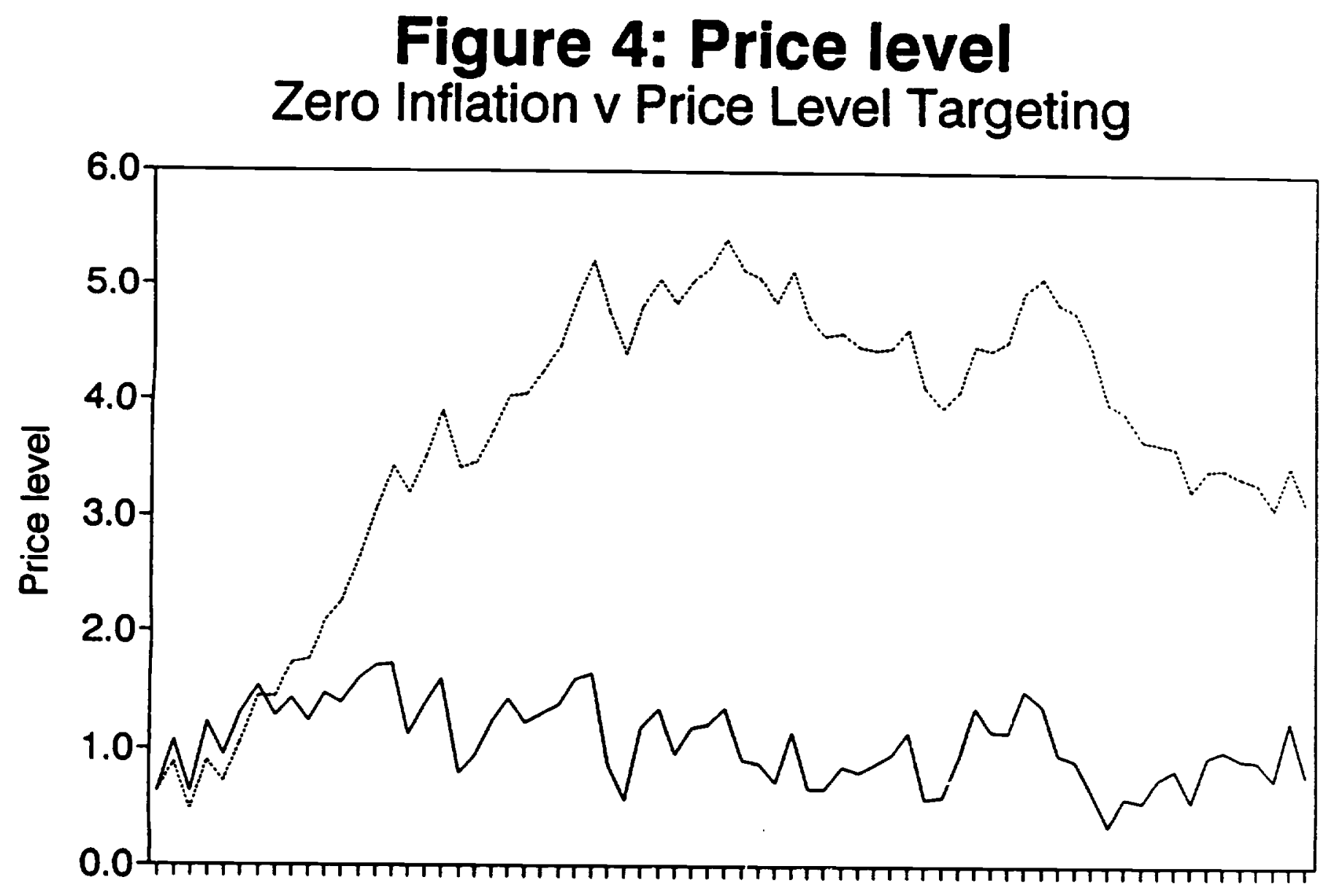




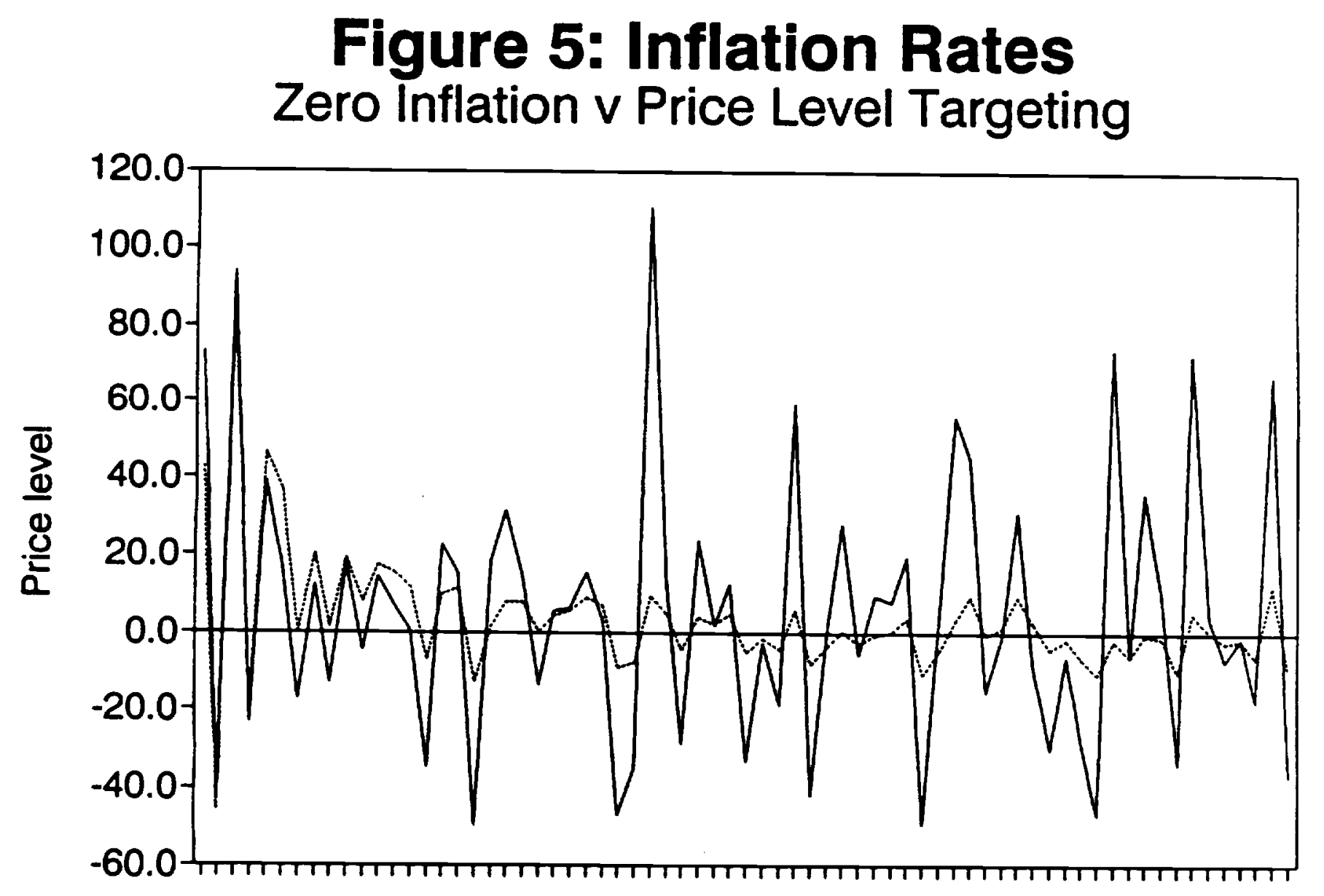

- Price level Z Zero Inflation 


\section{Figure 6: Inflation and CBI GMT Index}

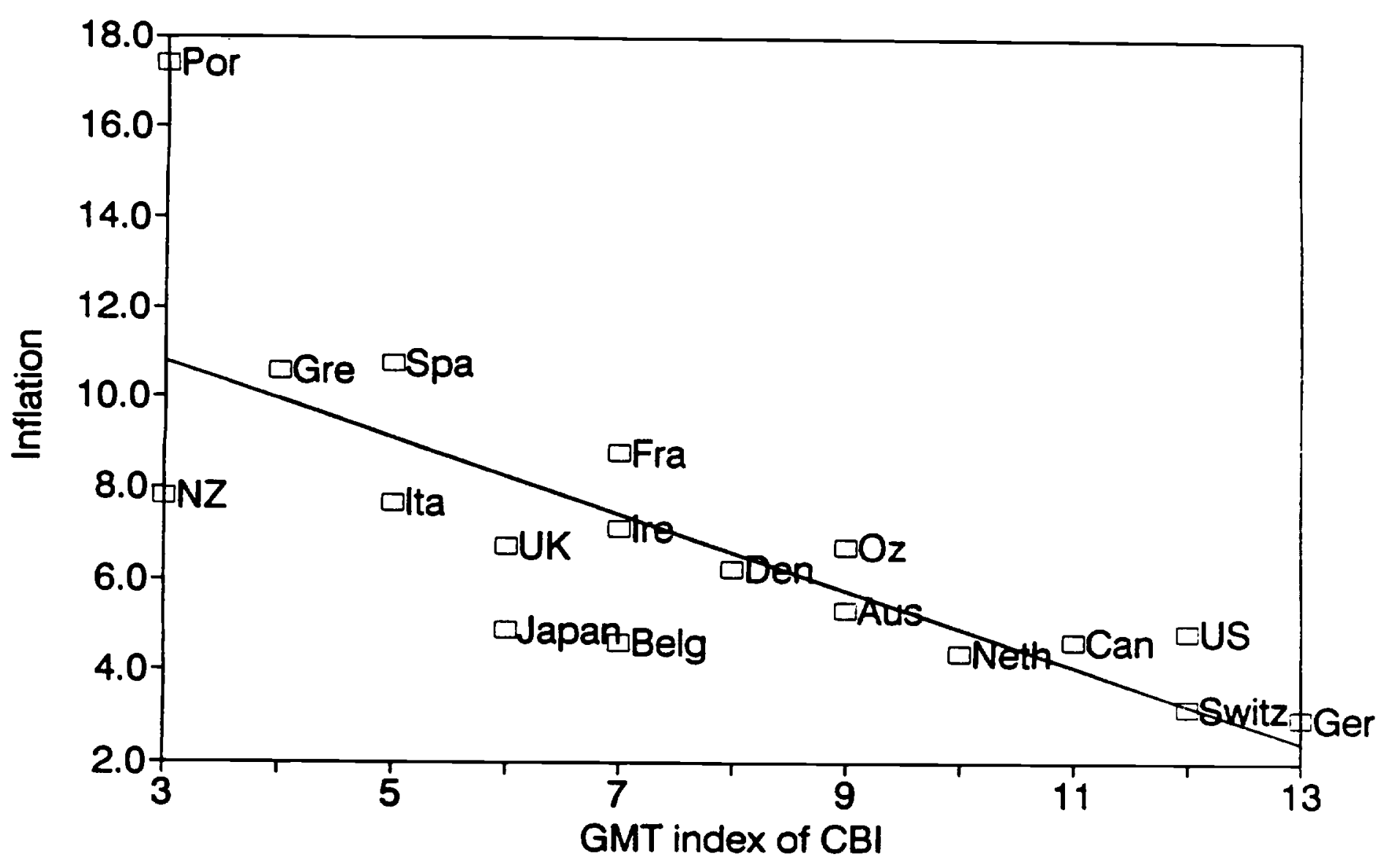




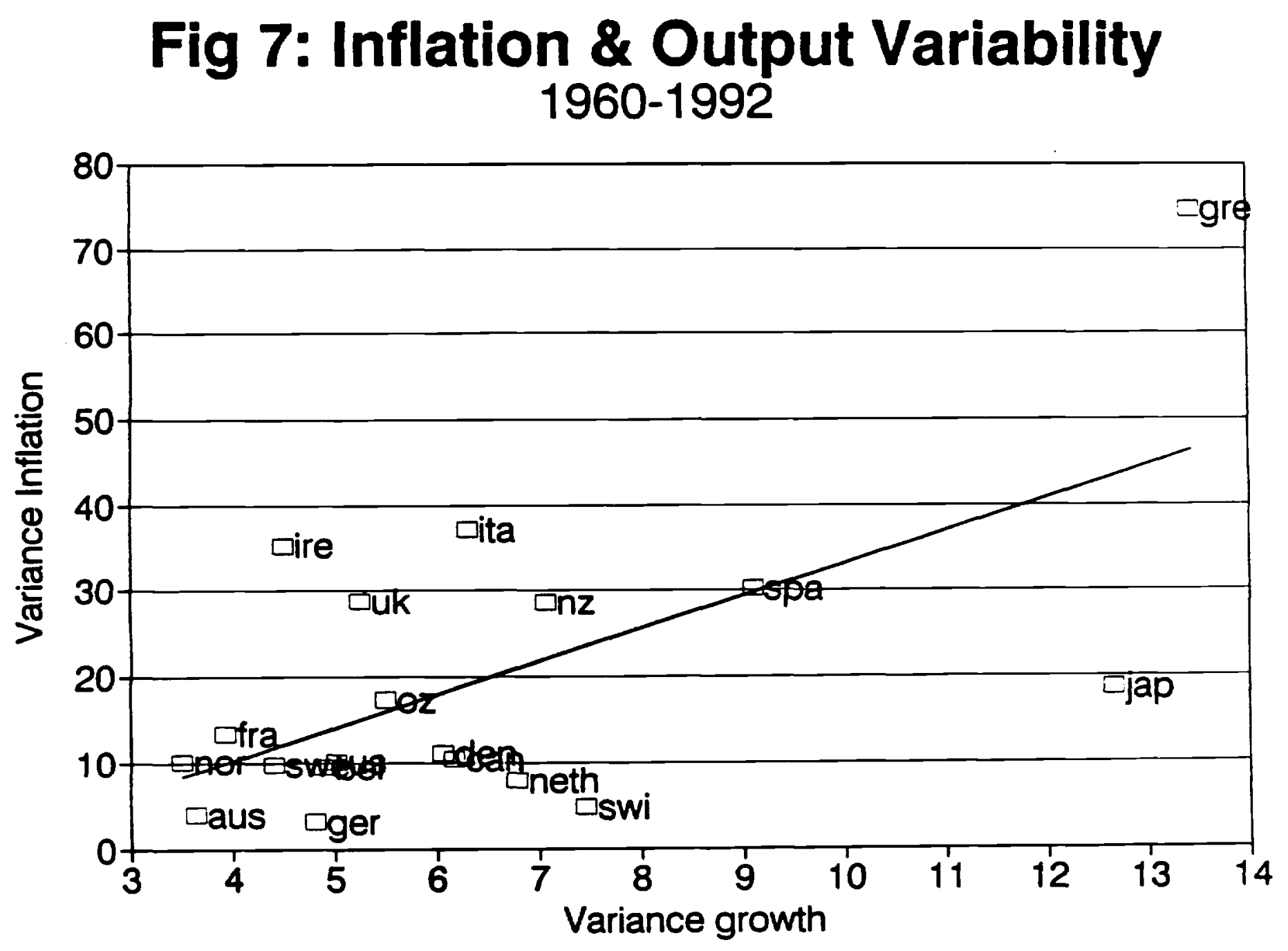

